\title{
The Production of Sustainable Concrete with the Use of Alternative Aggregates: A Review
}

\author{
Maria Cristina Collivignarelli ${ }^{1}{ }^{\mathbb{B}}$, Giacomo Cillari ${ }^{2}$, Paola Ricciardi ${ }^{1}{ }^{(}$, Marco Carnevale Miino ${ }^{1}(\mathbb{D}$, \\ Vincenzo Torretta ${ }^{3}\left[\right.$ (D) Elena Cristina Rada ${ }^{3, *}$ and Alessandro Abbà ${ }^{4}$ ) \\ 1 Department of Civil Engineering and Architecture, University of Pavia, via Ferrata 1, 27100 Pavia, Italy; \\ mcristina.collivignarelli@unipv.it (M.C.C.); paola.ricciardi@unipv.it (P.R.); \\ marco.carnevalemiino01@universitadipavia.it (M.C.M.) \\ 2 Department of Energy, Systems, Territory and Constructions Engineering, University of Pisa, \\ Largo Lucio Lazzarino, 56126 Pisa, Italy; cillarigiacomo@gmail.com \\ 3 Department of Theoretical and Applied Sciences, Insubria University, Via G.B. Vico, 46, 21100 Varese, Italy; \\ vincenzo.torretta@uninsubria.it \\ 4 Department of Civil, Environmental, Architectural Engineering and Mathematics, University of Brescia, \\ via Branze 43, 25123 Brescia, Italy; alessandro.abba@unibs.it \\ * Correspondence: elena.rada@uninsubria.it; Tel.: +39-0332-21-8782
}

Received: 6 August 2020; Accepted: 21 September 2020; Published: 24 September 2020

check for updates

\begin{abstract}
The concrete industry is a core element of the building sector, but it has to deal with the increasing attention on the environmental issues related to the production process: increasing energy efficiency and the adoption of alternative fuels or raw materials represent the most relevant solutions. The present work analyses physical, mechanical, and environmental performances of concrete incorporating residues derived from four main sources (construction and demolition waste, residues from waste treatment, metallurgical industry by-products, and others), as substitutes of either fine or coarse aggregates. Fine aggregates showed the highest number of alternatives and replacement level, with the relevant impact on concrete properties; coarse aggregates, however, always reach a complete replacement, with the exclusion of glass that highly affects the mechanical performance. Construction and metallurgical industry categories are the main sources of alternative materials for both the components, with ceramic and lead slag reaching a full replacement for fine and coarse aggregates.
\end{abstract}

Keywords: green concrete; waste management; compressive strength; physical properties; environmental compatibility; circular economy

\section{Introduction}

Concrete still represents one of the most relevant and used materials in the building industry, as it can be considered "the second most consumed substance on Earth after water" [1]. The production process is related to a significant carbon footprint, around $850 \mathrm{~kg}$ of $\mathrm{CO}_{2}$ emitted per ton of clinker [2], mainly due to the production of cement that requires a large quantity of resources, both in terms of energy and raw materials. Recommendation from the International Energy Agency (IEA) [3] include the increase in energy efficiency and the use of alternative materials, either fuels or raw materials, as the main means to decrease the environmental impact of concrete products. Investigations [4] highlight that the building sector offers the largest cost-effective greenhouse gas mitigation potential. From this point of view, aggregates play a core role as they account for about $80 \%$ to $85 \%$ of a typical concrete mixture and are responsible for an unsustainable local natural resources consumption [5]. Sand and gravel are the main resources extracted for aggregates production and traded by volume causing river 
deltas and coastlines erosion. The use of substitutes and alternative materials is a suitable mean to prevent or reduce river and marine ecosystems damage [6].

Aggregates play a role in defining concrete compressive strength. They are usually divided into coarse and fine aggregates, with a diameter less than $4.00 \mathrm{~mm}$. The different quality and kind of aggregates determine a different durability and workability that affect the concrete; great attention is given to avoid any chemical that can cause deterioration. The size of the aggregate depends on the final use of concrete and influence materials proportions: if the aggregate diameters are larger, a smaller quantity of cement and water is needed. Crushed stones, sand, rock quarries, and gravel are the most common materials used as aggregates, while recycled concrete and marine aggregates represent a possible, uncommon alternative $[7,8]$.

The possible impact of alternative materials depends on the construction industry size. The building construction economy has shown a slightly recovery in the last years: according to the Italian Technical and Economic Association of Precast Concrete (ATECAP) [9] report, the concrete production in Italy is marginally increasing, moving from $25.3 \mathrm{Mm}^{3}$ in 2015 to $27.3 \mathrm{Mm}^{3}$ in 2017 [10], a trend confirmed by the Italian Association of Building Contractors (ANCE) [11,12]. The European production of aggregates increased around 2.5\% since 2015, with Russia as the largest producing country with $592 \mathrm{Mt}$ in 2016 [13].

The integration of alternative materials help both saving natural resources and reducing waste disposal by incorporating urban and industrial wastes into concrete, according to the concept of circular economy [14]. The evaluation of the environmental benefits led by the use of recycled materials in common building elements is usually carried out by a Life Cycle Assessment in terms of primary embodied energy and greenhouse gas emissions, considering a "cradle-to-gate" approach [15]. Waste reduction policies promoted at international levels could reduce this strategy in the long terms $[16,17]$. Last data from the Italian Technical and Economic Cement Association (AITEC) sustainability report [18] show that Italy is still far from European average value of 40\% [19], underlying the need for a higher information and engagement for producers and stakeholders.

Incorporation of more alternative and sustainable raw materials from suitable waste streams is the future challenge of the concrete industry. While common production fuels can be replaced by biomass or other kinds of wastes [20], both part of fine and coarse aggregates can be made of recycled materials like scrap tyres, glass, and foundry sands, but this strategy is limited by technical issues and national regulations. The substitution of fuels and raw materials with alternative materials represents an important contribution to the circular economy, as it guarantees a feasible solution to waste management: concrete is relevant for the implementation of circular economy plans in the building sector as the most used 100\% recyclable building material [21-23]. According to the cement sustainability initiative and the European Cement Research Academy (ECRA), the average substitution rate of concrete components with waste and by-products in Europe reaches more than $60 \%$ for an industry sector and up to $95 \%$ as a yearly average for single cement plants [24,25].

To properly promote the integration of waste materials in concrete, sustainable practices and an increasing demand represent the most relevant driving factors [26,27]. Alternative materials are a suitable answer to the rising cost of raw materials and the consumption of natural resources [21]. Their contribution to sustainable development comes together with specific effects on the performances of produced concrete [28]. Looking specifically to aggregates, use of alternative materials must consider the effect on both mechanical properties and durability, related to porosity and water absorption, as the most affected parameters: final specimens must comply technical requirements in terms of resistance. The present review analyses physical, mechanical, and environmental performances of the both fine and coarse aggregates incorporating wastes from four main sources: (i) construction and demolition waste, (ii) residues from waste management treatment, (iii) metallurgical industry by-products, and (iv) other by-products that does not fit in any previous sector. The aim is to provide an extensive review of possible alternative aggregates and the effects of the substitution on the characteristics of the final concrete. 


\section{Methodological Approach}

Scopus and Google Scholar databases were the main sources for the bibliometric research, as two of the most common and wider online sources, to get transversal results on different kinds of waste. Keywords such as "green concrete", "alternative sustainable coarse aggregate", or "alternative sustainable fine aggregate" have been used and the results have been crossed with key terms like waste and recycled. The research focused mainly on works published in the last 10 years. The first step of the research was a preliminary screening of the found articles and reviews on source materials. We set the main categories of source materials, a second search was performed, looking for articles and studies on properties and performances of concretes made with a mix design that includes waste materials. The review is based on around 120 articles that have been divided into the four categories of wastes analysed. For each suitable alternative material, a brief description of its origin and/or composition, the stabilization methods, when needed, and the maximum replacement level detected is given. Then, physical and mechanical properties and environmental compatibility are described for each possible substitute. As mechanical properties strictly depend on target performance, values of reference concrete $(\mathrm{RC})$ are reported.

\section{Results}

Aggregates are one of the easiest components to substitute in mix design. The classification on fine and coarse aggregates strictly depends on the diameter of the component: the most common fine aggregates in RC are sand or crushed stone. Coarse aggregates play a role in determining the final strength of concrete composite. The increasing demand of such components for the concrete industry is depleting natural resources, so alternative solutions must be found to substitute them in the production process. The integration of recycled wastes and by-products in concrete is a sustainable alternative for the disposal of such materials, generally directed to landfills or incinerators: municipal solid waste incineration (MSWI) ashes and metallurgical industry by-products represent the most hazardous wastes, in terms of possible environmental impact and quantity, that can be used as aggregate in concrete. Recycled aggregates are another relevant option, embodying a possible closed-loop circular economy example in the building sector. Looking at the concrete components, fine aggregates are the easiest element to replace in terms of number of alternatives. Coarse aggregates, as shown in Figure 1, theoretically can always reach a complete replacement, with the exclusion of glass that highly affect the mechanical performance, but legislations limit a full substitution to few countries. Construction and metallurgical industry categories are the main sources for alternative materials for both the components, with ceramic and lead slag reaching a full replacement for both fine and coarse aggregates. In addition to lead slag and ceramic, blast furnace slag and glass are the most versatile as possible substitute of both kinds of aggregates. Replacement levels are reported in Figure 1. Looking to percentages, aggregates are fully replaceable, and they mainly must provide mechanical resistance to the paste and a chemical compatibility with other concrete components. Quarry dust and incinerator sewage sludge ash (ISSA) for fine aggregates, and glass for coarse ones, are the only alternative materials with a replacement level below $50 \%$, due to their high impact on the mechanical performance of concrete.

\subsection{Construction and Demolition Wastes}

A possible building waste to recover in the concrete industry is ceramic waste. It can replace sand in mix design. An increasing amount of the waste ceramic content proportionally with reduces the workability for Portland cement concrete. However, the presence of fly ash (FA) in concrete with ceramic waste guarantees a good workability even with a complete replacement of sand. The FA influences the overall performance: without FA, the compressive strength drops down over a $50 \%$ replacement level, due to the angular shape of the ceramic particles that reduce the workability. FA concrete instead has shown the opposite behaviour [29]. Looking at building industry, a natural substitute of sand can be granite quarry dust. As a waste of granite production, this dust is "a felsic 
crystalline rock with interlocking texture and visible mineral grains" [30]. Available with a particle size lower than $5.0 \mathrm{~mm}$, granite dust is perfectly suitable as fine aggregates. Despite a complete replacement being achievable for structural-related use, $50 \%$ has been suggested as the maximum replaceable share [31].

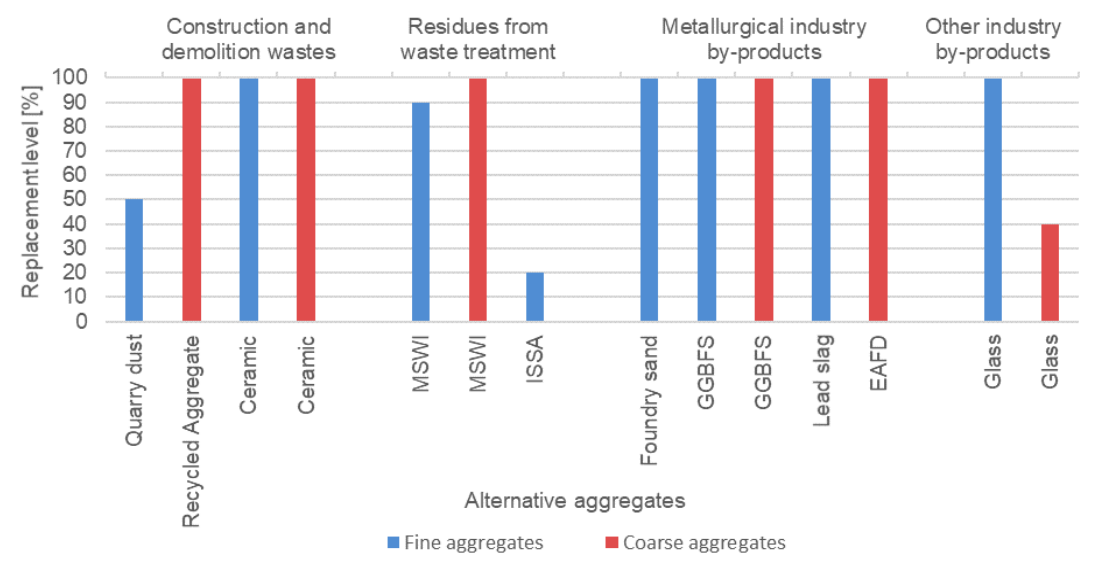

Figure 1. Maximum replacement level (expressed in \%) of by-products and wastes for any aggregate ingredient. MSWI: municipal solid waste incineration, ISSA: incinerator sewage sludge ash, GGBFS: ground granulated blast furnace slag, EAFD: electric arc furnace dust.

Recycled aggregates, from mixed demolition wastes, are the most common alternative solution for green concretes. They are usually generated from crushed concrete or old composites to replace coarse aggregates with a larger diameter. Recycled concrete aggregate is made of a minimum of 95\% crushed concrete. Various processes exist to produce quality recycled aggregates: plain and reinforced concrete detritus can be crushed using primary and secondary crushers. Resulting material usually contains pieces of metals, wood, or plastics that must be mechanically or manually removed before crushing. Common quality practices include crushing, screening, magnetic separation, and dry separation [32]. Recycled aggregates have been widely investigated in recent years and research has led to the conclusion that they have lower properties than corresponding natural aggregates [33,34]. The decrease in concrete quality firstly depends on the quality itself of the waste used. On the same mix proportion and workability, recycled aggregate concretes with $100 \%$ coarse aggregates substitution have an average compressive and tensile strength around 10-25\% lower than ordinary concrete, with a $5 \%$ to $35 \%$ lower modulus of elasticity [35,36]. This lower performance is mainly associated with the cracks that generate during production: recycled coarse aggregates become more susceptible to permeation and absorption of fluids [37]. Literature results in terms of carbonation processes are contradictory: carbonation depth generally decreases with the percentage of recycled aggregate [38], but some investigations have shown opposite results $[39,40]$. The difference in the original aggregate influenced the result, but the different behaviour may be caused by test methodology, accelerated carbonation test in the first study, as the duration of exposure highly affects carbonation depth: the higher the exposure period, the higher the depth is.

Used in powder to replace sand, ceramic tile waste is also a possible substitute for coarse aggregates. Concrete mixtures with ceramic aggregates showed better performances than the control mixtures: with $20 \%$ of ceramic coarse aggregates, a similar compressive strength to high-performance conventional concretes can be achieved. Samples at $50 \%$ of replacement level at 180 days of curing have showed a low corrosion risk. A full replacement is achievable [41]. The properties of alternative aggregates from construction and demolition waste are listed in Table 1. 


\subsubsection{Physical Properties}

Slump tests conducted over different samples integrating ceramic powder showed from 16 to $20 \mathrm{~mm}$ as the results for $15-30 \%$ fine aggregates substitution [42]. Dry density of specimens does not diverge from ordinary concrete, as for pore volume [43,44]. The samples studied by Lim et al. [30] with quarry dust integration showed a very high specific gravity and bulk density $\left(3560 \mathrm{~kg} / \mathrm{m}^{3}\right)$ due to the high iron content present in the electric arc furnace slag used as coarse aggregates.

The main consequence of the use of alternative coarse aggregate is the reduction in density caused by the lower bulk density of residues if compared to natural aggregates. Another common effect is the reduction in slump and initial workability, due to the higher water absorption, and the increase in porosity, that lead to a higher sensitivity to corrosion.

Incorporating ceramic coarse aggregates highly influence physical properties of concrete: the density decreases and, at the same time, absorption and voids volume increase with the replacement level [44]. Slump test results, around $40-50 \mathrm{~mm}$, are in accordance with these data [42].

Recycled coarse aggregates showed a wide range of variation for slump depending on replacement level: data reported by Limbachiya et al. [39] underline an inverse proportion among slump effect and replacement share for conventional Portland cement, and a linear one for cement with FA integration. The incorporation of recycled aggregates led to an increase in thermal conductivity, which stood in a range of $0.7-1.1 \mathrm{~W} /(\mathrm{m} \mathrm{K})[34]$. Nevertheless, composites are highly porous, nearly twice the porosity of normal concretes: this is a consequence of the higher porosity of the recycled aggregates, so the effect increases with the substitution. As a result, these concretes are more permeable to oxygen, double that of RC even if still relatively low. Higher water absorption rate and sensitivity to corrosion represent two additional dangerous side effects [45].

\subsubsection{Mechanical Properties}

Mechanical performance of the final specimens is strictly influenced by the resistance of aggregates. Construction and demolition waste is the class that showed the higher potential in terms of strength improvements: the compressive, flexural, and tensile resistance increased with the use of ceramic fine aggregates.

Results have shown that concrete produced with up to $30 \%$ of fine ceramic aggregates reach similar or improved mechanical properties than conventional concrete. According to some investigations $[46,47]$ compressive strength of concretes with fine ceramic sand is higher than ordinary concretes, while other research got lower values [48]: the difference is due to the different quality of recycled ceramic wastes adopted, with a related different water absorption level. Compressive strength range between the reference and the studied specimens was higher during the first days: fine ceramic aggregate concretes achieved a greater early compressive strength as a result of their higher early absorption capacity as well as the higher specific surface of the fine aggregate. Flexural and tensile strengths were not highly affected by the substitution and so was the modulus of elasticity [44].

The quality of coarse aggregate directly influences the final performance of concrete, especially mechanical properties. Early stage improvements of mechanical resistance have been detected for construction and demolition wastes, but the long-term performance was lower than ordinary concretes due to the poor quality of artificial aggregates.

Investigations on coarse ceramic-based aggregates showed an increase in the compressive strength at an early stage, with an inverse proportion with replacement [48]. However, at 28 days, concretes presented lower values than RC, except for $20 \%$ coarse aggregate replacement. Early stage gain is mainly due to the high amount of free water within the mixture, while low final strength is linked to the poor quality of aggregate compared to conventional ones [44]. Recycled aggregates from old composites commonly follow this trend: research highlighted a decrease around $24-35 \%$ of mechanical properties [45]. Results achieved by Limbachiya et al. [32] instead, on recycled concretes, showed mechanical properties close to natural coarse aggregate concretes, with a slight deviation focused at high replacement levels. 


\subsubsection{Environmental Properties}

A critical element for the integration of alternative aggregates is the heterogeneity of the material that determines highly variable properties of the final product [49]. The demolition phase impacts on the characterization and quality of the recycled aggregates: a selective process produces high quality, with more stable aggregates, as the result of a specific kind of waste, while a non-selective demolition results in a less homogeneous material, with a lower average performance [50].

The effect of construction and demolition waste aggregates on the porosity of the final product influence the durability of concrete by increasing the sorptivity, the absorption capacity and the chloride-ion penetration.

Durability properties of the recycled aggregate concretes are comparable to those of conventional concretes. The sorptivity and the water absorption of samples investigated by Gonzalez-Corominas et al. [44] have reached values close to RC. However, the resistance to chloride-ion penetration decreased as the recycled aggregate content increased, even if it still fit in low-very low corrosion risk level. Except for water permeability, even oxygen permeability and chloride diffusion performances have shown better results [48].

The use of ceramic coarse aggregates decreases density, and so final strength, due to the higher voids volume. Therefore, specimens with a higher rate of ceramic aggregates showed a greater sorptivity at 28 days. Absorption capacity and chloride-ion penetration are greater as well [44]. Even water absorption values surpassed the RC performance, but oxygen permeability and chloride diffusion confirmed the good behaviour of ceramic-based concrete [48].

Recycled aggregates, as other alternative materials, represent an environmentally friendly solution to prevent the amount of waste disposed in landfill [51]. Results of leaching tests carried out by Sani et al. [52] showed that a cumulated ion releases slightly higher than conventional concrete.

Release of pollutants become a relevant parameter for gypsum wastes, which produce a high release of sulphates [53]. 
Table 1. Physical, mechanical, and environmental performance of concrete products with alternative aggregates from construction and demolition wastes.

\begin{tabular}{|c|c|c|c|c|c|c|c|c|}
\hline Aggregate & Property Class & $\begin{array}{l}\text { Substitute } \\
\text { By-Product }\end{array}$ & Property & $\begin{array}{l}\text { Replacement } \\
\text { Level }\end{array}$ & Value & $\begin{array}{c}\text { Unit of } \\
\text { Measurement }\end{array}$ & $\begin{array}{c}\text { Cement Type } \\
\text { (Water-to-Cement Ratio) }\end{array}$ & References \\
\hline \multirow{16}{*}{$\begin{array}{c}\text { Fine } \\
\text { aggregates }\end{array}$} & \multirow{4}{*}{$\begin{array}{l}\text { Physical } \\
\text { properties }\end{array}$} & \multirow{3}{*}{ Ceramic } & Density & $15-50 \%$ & $2179-2184$ & $\mathrm{~kg} / \mathrm{m}^{3}$ & \multirow{3}{*}{ ASTM Type I PC (0.2-0.5) } & \multirow[b]{2}{*}[42,44]{} \\
\hline & & & Slump test & $5-30 \%$ & $\begin{array}{l}16-20 \\
40-55\end{array}$ & $\mathrm{~mm}$ & & \\
\hline & & & Volume of permeable pore space & $5 \%$ & 3.25 & $\%$ & & [44] \\
\hline & & Granite dust & Density & $50 \%$ & 3560 & $\mathrm{~kg} / \mathrm{m}^{3}$ & OPC (0.35) & [30] \\
\hline & \multirow{5}{*}{$\begin{array}{l}\text { Mechanical } \\
\text { properties }\end{array}$} & \multirow{4}{*}{ Ceramic } & Compressive strength $(\mathrm{RC})^{1,2}$ & \multirow{4}{*}{$50-100 \%$} & $\begin{array}{c}33.7-35.7(33) \\
48(40) \\
109.1(102.6)\end{array}$ & \multirow{3}{*}{$\mathrm{MPa}$} & ASTM Type I PC 0.5-0.6) & {$[42,44,48]$} \\
\hline & & & Flexural strength (RC) ${ }^{3}$ & & $6.55-8.31(6.47)$ & & \multirow{3}{*}{ ASTM Type I PC (0.2-0.5) } & \multirow{3}{*}{ [44] } \\
\hline & & & Tensile strength (RC) ${ }^{1}$ & & $5.14-5.25(5.13)$ & & & \\
\hline & & & Modulus of elasticity (RC) ${ }^{1}$ & & $47.6-49.9(50.4)$ & GPa & & \\
\hline & & $\begin{array}{c}\text { Granite quarry } \\
\text { dust }\end{array}$ & Compressive strength $(\mathrm{RC})^{1,2}$ & $50 \%$ & $80(80)$ & $\mathrm{MPa}$ & OPC (0.31-0.35) & {$[30]$} \\
\hline & \multirow{7}{*}{$\begin{array}{c}\text { Environmental } \\
\text { properties }\end{array}$} & \multirow{7}{*}{ Ceramic } & Absorption capacity ${ }^{4}$ & $10-50 \%$ & 1.3 & \multirow[b]{2}{*}{$\%$} & ASTM Type I PC (0.285) & [44] \\
\hline & & & Vacuum water absorption ${ }^{4}$ & \multirow{5}{*}{$50-100 \%$} & 17 & & OPC $(0.5)$ & [48] \\
\hline & & & Water permeability & & $5-6 \times 10^{-17}$ & \multirow{2}{*}{$\mathrm{m}^{2}$} & ASTM Type I PC (0.285) & {$[42,48]$} \\
\hline & & & Oxygen permeability & & $8-9 \times 10^{-17}$ & & \multirow{4}{*}{ OPC $(0.5)$} & \multirow{4}{*}{ [48] } \\
\hline & & & Chloride-ion penetration ${ }^{1,4}$ & & $1000 \mathrm{C}$ & $\mathrm{C}$ & & \\
\hline & & & Chloride-ion diffusion ${ }^{1,4}$ & & $23-26 \times 10^{-12}$ & $\mathrm{~m}^{2} / \mathrm{s}$ & & \\
\hline & & & Sorptivity ${ }^{1}$ & $10-50 \%$ & $0.015-0.016$ & $\mathrm{~mm} / \min ^{\frac{1}{2}}$ & & \\
\hline \multirow{6}{*}{$\begin{array}{c}\text { Coarse } \\
\text { aggregates }\end{array}$} & \multirow{6}{*}{$\begin{array}{l}\text { Physical } \\
\text { properties }\end{array}$} & \multirow{6}{*}{$\begin{array}{l}\text { Recycled } \\
\text { Aggregates }\end{array}$} & Density & \multirow{4}{*}{$10-100 \%$} & 1800-1970 & $\mathrm{kg} / \mathrm{m}^{3}$ & PC CEM I 52.5 (0.5-0.55) & {$[33,44,51]$} \\
\hline & & & Slump ${ }^{5}$ & & $20-70$ & $\mathrm{~mm}$ & $\begin{array}{l}\text { CEM IIA-LL } 42.5 \\
\quad(0.5-0.74)\end{array}$ & {$[39,54]$} \\
\hline & & & Porosity & & $6-23$ & $\%$ & CEMII/A-L42.5R (0.6) & {$[52,55]$} \\
\hline & & & Thermal conductivity & & $0.7-1.1(0.65)$ & $\mathrm{W} /(\mathrm{m} \mathrm{K})$ & \multirow{3}{*}{ ASTM type I OPC (0.29) } & {$[34,56]$} \\
\hline & & & Weighted sound reduction index & \multirow{2}{*}{$50 \%$} & 64 & \multirow[b]{2}{*}{$\mathrm{dB}$} & & \multirow[b]{2}{*}{ [56] } \\
\hline & & & $\begin{array}{l}\text { Weighted normalised impact } \\
\text { sound pressure level }\end{array}$ & & 77 & & & \\
\hline
\end{tabular}


Table 1. Cont.

\begin{tabular}{|c|c|c|c|c|c|c|c|c|}
\hline Aggregate & Property Class & $\begin{array}{l}\text { Substitute } \\
\text { By-Product }\end{array}$ & Property & $\begin{array}{l}\text { Replacement } \\
\text { Level }\end{array}$ & Value & $\begin{array}{c}\text { Unit of } \\
\text { Measurement }\end{array}$ & $\begin{array}{c}\text { Cement Type } \\
\text { (Water-to-Cement Ratio) }\end{array}$ & References \\
\hline \multirow{23}{*}{$\begin{array}{c}\text { Coarse } \\
\text { aggregates }\end{array}$} & \multirow{4}{*}{$\begin{array}{l}\text { Physical } \\
\text { properties }\end{array}$} & \multirow{4}{*}{ Ceramic } & Density & $20-100 \%$ & $2190-2430$ & \multirow{2}{*}{$\mathrm{kg} / \mathrm{m}^{3}$} & \multirow{4}{*}{ ASTM Type II PC (0.5-0.6) } & {$[42,44]$} \\
\hline & & & Bulk density & \multirow{2}{*}{$50 \%$} & 1584 & & & \multirow{2}{*}{ [42] } \\
\hline & & & Slump & & $40-50$ & $\mathrm{~mm}$ & & \\
\hline & & & Volume of permeable pore space & $20-100 \%$ & $4.55-8.70$ & $\%$ & & [44] \\
\hline & \multirow{10}{*}{$\begin{array}{l}\text { Mechanical } \\
\text { properties }\end{array}$} & \multirow{5}{*}{$\begin{array}{l}\text { Recycled } \\
\text { Aggregates }\end{array}$} & \multirow[t]{2}{*}{ Compressive strength (RC) ${ }^{1}$} & \multirow{5}{*}{$10-100 \%$} & $20-27(17)$ & \multirow{4}{*}{$\mathrm{MPa}$} & $\begin{array}{l}\text { OPC (0.5) } \\
\text { PC }\end{array}$ & \multirow{2}{*}{$31,33,38,44,53$} \\
\hline & & & & & $24.4(39.8)$ & & CEM I 42.5 R/SR (0.5-0.6) & \\
\hline & & & Flexural strength $(\mathrm{RC})^{1}$ & & $4.3-4.5(4.4)$ & & $\begin{array}{l}\text { CEM I } 52.5 \mathrm{~N} / \mathrm{SR} \\
(0.45-0.65)\end{array}$ & {$[31,38,53]$} \\
\hline & & & Tensile strength (RC) $^{1}$ & & $2.6(3.1)$ & & PC CEM I 52.5 N (0.63) & [45] \\
\hline & & & Modulus of elasticity (RC) ${ }^{1}$ & & $19.6(30.8)$ & GPa & $\begin{array}{c}\text { PC CEM I } 52.5 \mathrm{~N} / \mathrm{SR} \\
(0.45)\end{array}$ & {$[31,38,44]$} \\
\hline & & & Compressive strength $(\mathrm{RC})^{1}$ & & $25.7-28.2(26.9)$ & & PC CEM I 42.5R & {$[41,43,47]$} \\
\hline & & & & & 72-101 (102) & & & \\
\hline & & Ceramic & Flexural strength (RC) ${ }^{1}$ & $20-100 \%$ & $4.7-6.9(5-7)$ & $\mathrm{MPa}$ & & \\
\hline & & & Tensile strength (RC) $^{1}$ & & $4.2-4.6(5.13)$ & & ASTM Type II PC (0.5-0.6) & {$[44,57]$} \\
\hline & & & Modulus of elasticity (RC) ${ }^{1}$ & & $32.3-43.9(50.4)$ & & & [44] \\
\hline & & & $\mathrm{pH}$ & & 12 & & $\begin{array}{c}\text { PC CEM II/A-LL } 42.5 \\
(0.74)\end{array}$ & [54] \\
\hline & & & & $0-100 \%$ & 0.18 & $\mathrm{mg} \mathrm{Cr} / \mathrm{kg}$ & & \\
\hline & & & Release of pollutants ${ }^{6,7}$ & $0-1007 \%$ & 0.007 & $\mathrm{mg} \mathrm{Zn} / \mathrm{kg}$ & PC CEM I $52.5 \mathrm{~N}(0.5)$ & {$[58,59]$} \\
\hline & & & & & 0.011 & $\mathrm{mg} \mathrm{As} / \mathrm{kg}$ & & \\
\hline & $\begin{array}{l}\text { Environmental } \\
\text { properties }\end{array}$ & $\begin{array}{l}\text { Recycled } \\
\text { Aggregates }\end{array}$ & Vacuum absorption capacity & $20-100 \%$ & $9.9-11.2$ & $\%$ & $\begin{array}{c}\text { PC CEM I } 52.5 \mathrm{~N} \\
(0.63-0.65)\end{array}$ & {$[45,55]$} \\
\hline & & & Permeable coefficient & & $2-2.5$ & $\mathrm{~mm} / \mathrm{s}$ & $\begin{array}{c}\text { ASTM type I OPC } \\
(0.29-0.45)\end{array}$ & [34] \\
\hline & & & Cumulated ion releases ${ }^{8}$ & $0-100 \%$ & 4.5 & $\mathrm{mS} / \mathrm{cm}$ & PC CEMII/A-L42.5R (0.6) & {$[52]$} \\
\hline & & & Soluble sulphate in water & & 2.4 & $\% \mathrm{SO}_{3}{ }^{-}$ & PC CEM I 52.5 N (0.65) & [59] \\
\hline & & & Soluble sulphate in acid & & 2.6 & & & \\
\hline
\end{tabular}


Table 1. Cont.

\begin{tabular}{|c|c|c|c|c|c|c|c|c|}
\hline Aggregate & Property Class & $\begin{array}{l}\text { Substitute } \\
\text { By-Product }\end{array}$ & Property & $\begin{array}{l}\text { Replacement } \\
\text { Level }\end{array}$ & Value & $\begin{array}{c}\text { Unit of } \\
\text { Measurement }\end{array}$ & $\begin{array}{c}\text { Cement Type } \\
\text { (Water-to-Cement Ratio) }\end{array}$ & References \\
\hline & & \multirow{12}{*}{ Ceramic } & $\mathrm{pH}^{9}$ & \multirow{5}{*}{$25 \%$} & 8.5 & & \multirow{5}{*}{ CEM I 52.5 N/SR (0.45) } & \multirow{5}{*}[60]{} \\
\hline & & & $\begin{array}{l}\text { Electrical conductivity of } \\
\text { leachate }\end{array}$ & & 432 & $\mu \mathrm{S} / \mathrm{cm}$ & & \\
\hline & & & \multirow{3}{*}{ Release of pollutants ${ }^{9}$} & & 0.065 & $\mathrm{mg} \mathrm{B} /\left(\mathrm{dm}^{2} \mathrm{~d}\right)$ & & \\
\hline & & & & & 0.038 & $\mathrm{mg} \mathrm{Si} /\left(\mathrm{dm}^{2} \mathrm{~d}\right)$ & & \\
\hline & & & & & 0.028 & $\mathrm{mg} \mathrm{Cl} /\left(\mathrm{dm}^{2} \mathrm{~d}\right)$ & & \\
\hline & & & Absorption capacity & $20-100 \%$ & $1.88-3.97$ & $\%$ & $\begin{array}{c}\text { ASTM Type II PC } \\
(0.5-0.6)\end{array}$ & {$[42,44]$} \\
\hline & & & Vacuum water absorption & \multirow{3}{*}{$50 \%$} & 18 & $\%$ & \multirow{3}{*}{ ASTM type I OPC (0.55) } & \multirow{3}{*}{ [48] } \\
\hline & & & Water permeability & & $6 \times 10^{-17}$ & $\mathrm{~m}^{2}$ & & \\
\hline & & & Oxygen permeability & & $9 \times 10^{-17}$ & $\mathrm{~m}^{2}$ & & \\
\hline & & & Chloride-ion penetration ${ }^{1}$ & $20-100 \%$ & $1100-1600$ & $\mathrm{C}$ & $\begin{array}{c}\text { ASTM Type II PC } \\
(0.5-0.6)\end{array}$ & [44] \\
\hline & & & Chloride-ion diffusion ${ }^{1}$ & $50 \%$ & $26 \times 10^{-12}$ & $\mathrm{~m}^{2} / \mathrm{s}$ & ASTM type I OPC (0.55) & [48] \\
\hline & & & Sorptivity ${ }^{1}$ & $20-100 \%$ & $0.021-0.036$ & $\mathrm{~mm} / \min ^{\frac{1}{2}}$ & $\begin{array}{c}\text { ASTM Type II PC } \\
(0.5-0.6)\end{array}$ & [44] \\
\hline
\end{tabular}

RC: reference concrete; MSWI: municipal solid waste incineration; ISSA: incinerator sewage sludge ash; GGBFS: ground granulated blast furnace slag; EAFD: electric arc furnace dust; ASTM: American Society for Testing and Materials; OPC: ordinary portland cement; PC: Portland; CEM: cement. ${ }^{1}$ at 28 days; ${ }^{2}$ average; ${ }^{3} 7$ days; ${ }^{4}$ average; ${ }^{5} 30$ MPa compressive strength targets at 28 days; ${ }^{6}$ liquid to solid ratio $2 ;{ }^{7}$ EN $12457-3 ;{ }^{8} 100 \mathrm{~h} ;{ }^{9}$ according to EN 14944-3. 


\subsection{Residues from Waste Treatment}

MSWI ash has been tested as a proper solution for fine aggregates: "bulk chemical compositions of these wastes are similar to the compositions of various raw materials" so they can be incorporated as substitute of different concrete components [61,62]. MSWI Bottom Ash (BA) can replace the granular portion of concrete, both fine and coarse aggregates [63]. With a replacement level of $20-40 \%$ on sand weight, higher BA content has shown lower slump, a general increase in both initial and final setting time, and a reduction in compressive strength $[64,65]$. In waste management field, ISSA is a residue that finds different application in concrete industry: from cement component to concrete element in ground form. However, in fine particles, it can be adopted as a fine filler aggregate [66]. Due to the decrease in final strength of hardened composites, exploiting ISSA as a substitute of fine aggregates results a more advantageous solution then replacing cement. In particular, dried sludge can theoretically totally replace sand in concrete production, bringing a higher water absorption capacity and porosity, even if a maximum substitution of $20 \%$ has been investigated with positive results [67].

Gravel and coarse aggregates find in the upgraded MSWI BA another proper substitute. Artificial aggregates are produced by stabilization/solidification methods in a rotary plate granulator [68]. Even if a higher rate can be reach, a maximum replacement level around $20 \%$ in volume for structural concrete and up to $50 \%$ for plain concrete guarantee final mechanical and durability properties to be quite close to those of the ordinary concretes, at the same compressive strength. However, MSWI ash concrete have shown a higher shrinkage, creep, and chloride-diffusion coefficients [69]. Collivignarelli et al. [58] underlined the critical points for the environmental compatibility of aggregates based on MSWI ash: (i) the high amount of heavy metals, which affects durability; (ii) the high content of chloride, which enhances the steel corrosion. The problems concerning expansion and cracking are due to the development of gaseous hydrogen caused by the corrosion of metals in an alkaline environment [70]. Table 2 shows the properties of alternative aggregates from residues from waste treatment.

\subsubsection{Physical Properties}

Residues from waste treatment led to a reduction in workability due to the hygroscopic behaviour of ISSA particles and the increase in porosity, for MSWI ash, that reduce the final density. Addition of MSWI fine ash as fine aggregate influences physical properties of concrete: the workability gradually decreases while the porosity linearly increases with the substitution rate. Samples with different substitution rate studied by Kuo et al. [7] reported, with a porosity range of $24-27.5 \%$, a slump test result of $270 \mathrm{~mm}$. Fineness of ISSA particles underline its suitability as a substitute for fine aggregates. However, according to data [71], increasing the ISSA share in concrete significantly affect the workability: over a $15 \%$ of substitution rate zero slump is achievable. The cause can be found in a reduction in water/cement ratio and in the "hygroscopic nature" of ISSA particles due to the particles work in cement matrix as free water absorbers [72]. The use of sewage sludge (SS) as a substitute of fine aggregates has caused a reduction in density and an increase in capillary water absorption, thus partially compromising mechanical performance [72].

MSWI ashes can be properly implemented also as a substitute of coarse aggregates. BA, in fact, can replace the whole share of coarse aggregates in a mixture. The incorporation of MSWI ash aggregates reduces both the density and the slump [73]. According to the test carried out by Sorlini et al. [74] the washed ashes present physical qualities that comply with the production of concrete mixtures.

\subsubsection{Mechanical Properties}

Investigations on mechanical performance of MSWI ash-based concretes by Tang et al. [74] clearly showed the influence of recycled fine aggregates on compressive and flexural strength: a loss of $25 \%$ has been registered for compressive resistance at $30 \%$ of substitution. Flexural resistance was less influenced by the replacement, with a maximum loss of $10 \%$ at $20 \%$ of MSWI ash content [75]. 
The use of ISSA fine aggregates in concrete, instead, brought an enhanced cohesion in the matrix structure. As a result, an increased strength has been detected [71]. Compressive strength at 28 days of samples studied by Jamshidi et al. [72], with $20 \%$ of ISSA and a 0.45 water-to-cement ratio, reached $33 \mathrm{MPa}$.

The effect of MSWI ash replacement as a coarse aggregate on the mechanical properties of concrete is notably less than as a fine aggregate: average compressive strength decrease at 28 days is around $5 \%$ at $25 \%$ MSWI ash content. As "the coarse fraction of the ash has lower absorption properties than the fine fraction", coarse aggregates have a lower interaction with the water movement and, along with higher concentration of sulphate and chloride salts, this may influence the hydration reaction and so the strength development [73]. Abbà et al. [70] noticed that the cement type of the mixture had a relevant role for the final performance, on an average base. The mixture with $42.5 \mathrm{R}$ cement showed improvements both in compressive and tensile resistance, reducing the gap with ordinary concrete design.

\subsubsection{Environmental Properties}

Long-term performance of MSWI ash fine aggregates exceed the limit for concrete application: the leaching of $\mathrm{Pb}$ and $\mathrm{Zn}$ increased in MSWI ash concretes, with high concentration caused by the high $\mathrm{pH}$ environment.

Leaching test conducted on concrete samples made with MSWI ash fine aggregates has reported values lower than the untreated wastes for a series of pollutants, clearly confirming the effectiveness of the concrete stabilization. The leaching of $\mathrm{Cu}$ has been reduced, but on the other hand, leaching of $\mathrm{Pb}$ and $\mathrm{Zn}$ from the concretes containing wastes were in general higher than from the single waste. The concentrations of $\mathrm{Cu}$ and $\mathrm{Pb}$ exceeded the respective limit values. However, the lower levels of some elements from the mortar are due to chemical processes occurring during cement hydration. The high $\mathrm{pH}$ environment, instead, causes the high concentrations of $\mathrm{Cu}, \mathrm{Pb}$, and $\mathrm{Zn}$ [71].

Washing treatment is a common step in processing MSWI ashes to reduce the chloride content and prevent the reinforced concrete from corrosion risk. Leaching test results conducted by Keulen et al. [76] complied with standard reference: only salts release, mainly $\mathrm{Cl}$ and $\mathrm{Br}$, increased at high replacement levels. Collivignarelli et al. [58] confirmed the environmental compatibility of MSWI ash aggregates in concrete by means of leaching tests, achieving a lower release than sand for chlorine, chromium, and bromine. The pollutants mobility and concentration have been highly influenced by the $\mathrm{pH}$ [77]. According to data reported by Sorlini et al. [65], different tests resulted in critical outcomes for different elements: 16 days leaching test for the release of anions, single stage in water for $24 \mathrm{~h}$ regarding the metals. Heavy metals critical values have been achieved in an acetic acid leaching test. However, the investigation confirmed that the overall leaching behaviour of the concrete with MSWI ash coarse aggregates was similar to natural concrete. 
Table 2. Physical, mechanical, and environmental performance of concrete products with alternative aggregates from residues from waste treatment.

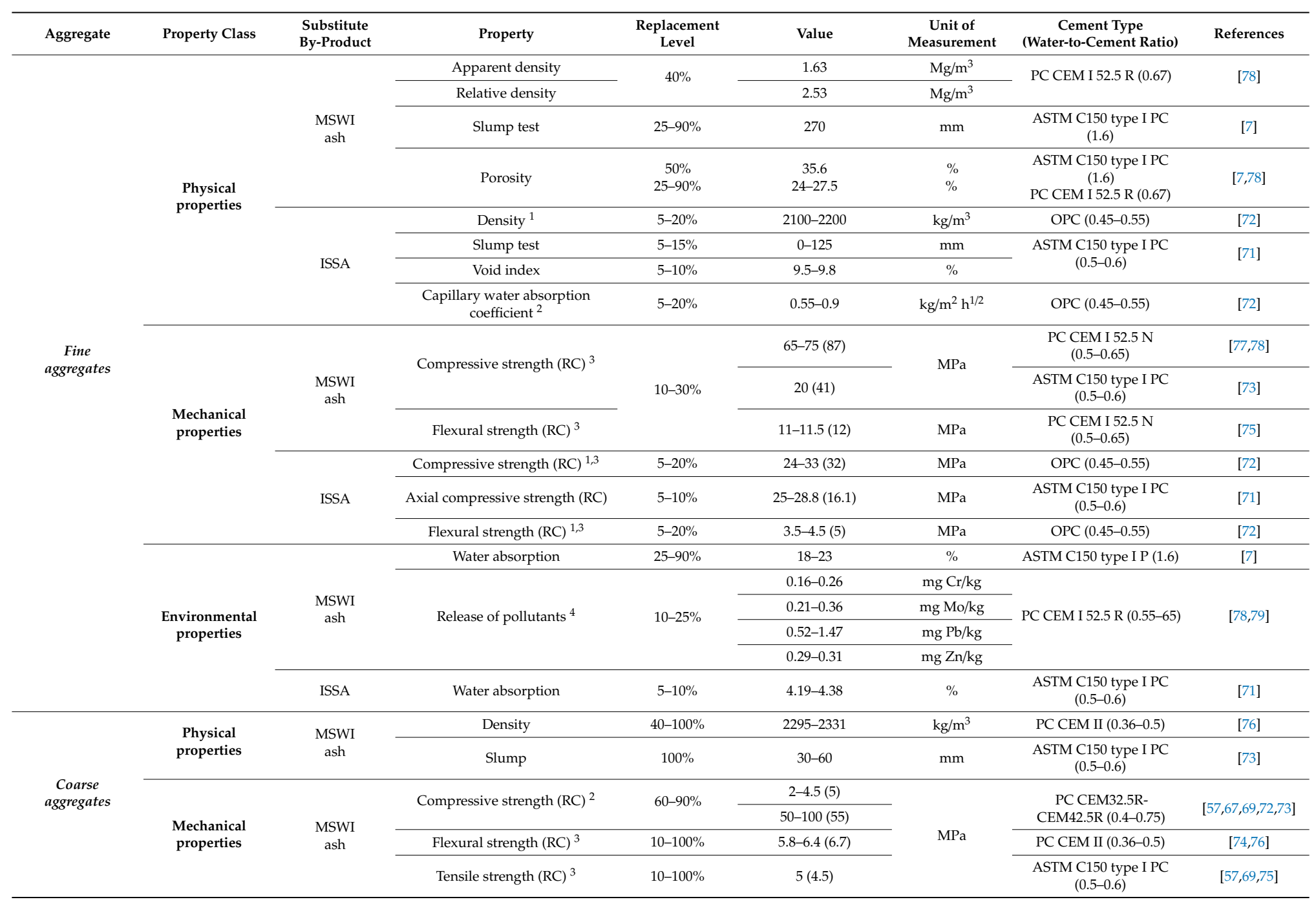


Table 2. Cont.

\begin{tabular}{|c|c|c|c|c|c|c|c|c|}
\hline Aggregate & Property Class & $\begin{array}{l}\text { Substitute } \\
\text { By-Product }\end{array}$ & Property & $\begin{array}{l}\text { Replacement } \\
\text { Level }\end{array}$ & Value & $\begin{array}{c}\text { Unit of } \\
\text { Measurement }\end{array}$ & $\begin{array}{c}\text { Cement Type } \\
\text { (Water-to-Cement Ratio) }\end{array}$ & References \\
\hline & \multirow{6}{*}{$\begin{array}{l}\text { Environmental } \\
\text { properties }\end{array}$} & \multirow{6}{*}{$\begin{array}{l}\text { MSWI } \\
\text { ash }\end{array}$} & \multirow{2}{*}{ Release of pollutants 9} & \multirow{2}{*}{$60-90 \%$} & $1-2$ & $\mathrm{mg} \mathrm{Zn/L}$ & Н С ЕIVI $152.0 \%(0.4-0.6)$ & \multirow{2}{*}[68,74]{} \\
\hline & & & & & $5-11$ & $\mathrm{mg} \mathrm{Cr} / \mathrm{L}$ & PC CEM32.5R (0.4-0.75) & \\
\hline & & & \multirow{3}{*}{ Release of pollutants ${ }^{10}$} & \multirow{4}{*}{$40-100 \%$} & 160 & $\mathrm{mg} \mathrm{Cl} / \mathrm{kg}$ & & \multirow{3}{*}[64,75,76]{} \\
\hline & & & & & 0.2 & $\mathrm{mg} \mathrm{Cu} / \mathrm{kg}$ & & \\
\hline & & & & & 1.6 & $\mathrm{mg} B r / \mathrm{kg}$ & PC CEM I 52.5 R (0.67) & \\
\hline & & & Release of pollutants ${ }^{11}$ & & $0.012-0.014$ & $\mathrm{mg} \mathrm{Ba} / \mathrm{L}$ & & {$[65,77]$} \\
\hline
\end{tabular}

RC: reference concrete; MSWI: municipal solid waste incineration; ISSA: incinerator sewage sludge ash; GGBFS: ground granulated blast furnace slag; ASTM: American Society for Testing and Materials; OPC: ordinary portland cement; PC: Portland; CEM: cement. ${ }^{1}$ with 0.55 water-to-cement ratio; ${ }^{2}$ with 0.45 water-to-cement ratio: ${ }^{3}$ at 28 days; ${ }^{4}$ according to EN $12457-2$; ${ }^{5}$ average; ${ }^{6}$ at $20{ }^{\circ} \mathrm{C} ;{ }^{7}$ at $55 \% \mathrm{RH} ;{ }^{8}$ at 200 days; ${ }^{9} 72 \mathrm{~h} ;{ }^{10}$ batch $\mathrm{pH}$-static leaching according to EN $14997 ;{ }^{11}$ according to UNI 10802. 


\subsection{Metallurgical Industry by-Products}

Moving to metallurgical industry, concrete has shown to be a suitable material where waste foundry sands (WFS) can be adopted to partially replace natural fine aggregates [28]. This is a high-quality sand coming as a by-product of industrial metal castings [80]. The partial replacement through solidification/stabilization process, not exceeding $20 \%$ by weight, leads to a final product with performances close to RC [81]. Processed ground granulated blast furnace slag (GGBFS) becomes a granular product that can be dried and ground into a fine powder. In this shape, it is a natural substitute for fine aggregates: a 100\% replacement of sand can be reached, but GGBFS incorporation hugely affects the final performance of composites. The compressive strength increased with an increasing GGBFS content [82]. Resistance to high temperature, surface abrasion, and durability properties of concrete are other characteristics affected by the substitution [83]. In road construction, there is a heavy metal industry waste suitable as a substitute: lead slag. Primary and secondary lead slag can be turned both in fine and coarse aggregates through a cement-based stabilization/solidification process [84]. It has shown a better grain size curve than sand itself, complying with the compressive strength requirements [85]. Alwaeli [86] has demonstrated that the incorporation of granulated lead-zinc slag in concrete works as a shield to the gamma radiation, so it would properly fit in laboratories construction where radiation are generally used. A full replacement of sand is theoretically achievable: results have shown that compressive strength increases with the content of lead slag.

Electric-arc furnace dust is a further typical metallurgical waste of the iron industry. Potentially, it can fully replace ordinary coarse aggregates [87]: benefits involve both mechanical and durability strength of final composite. Side effects of its incorporation, however, mainly concern the workability [88] and the dimensional stability performance [89]. The physical properties and chemical composition of electric-arc furnace dust widely varies according to the source, so a complete evaluation of its impact in concrete performance is difficult if not pre-processed to make it more stable [30]. The reduction in terms of workability is caused by a more uneven distribution of coarse aggregate size than RC, but both compressive, tensile, and shrinkage test attested the material reliability [90].

Blast furnace slag, instead, is a non-metallic by-product from iron industrial production, typically applied in asphalt concrete: it forms when iron is reduced into molten pig iron in blast furnaces. Depending on the final production process of the molten state iron, the slag can be classified into different types. Even if an increase in slag aggregates content generates a decrease in the mechanical properties of the final concrete, the loss of strength is very low with a complete replacement and nearly zero with a $50 \%$ of slag aggregates [91]. Table 3 lists the properties related to the alternative aggregates from metallurgical industry by-products.

\subsubsection{Physical Properties}

GGBFS presented the highest slump, around $180 \mathrm{~mm}$, among waste treatments residues, which instead reduced the workability. The use of high-density lead slag increased the density of concrete, while the glass had the opposite effect because of its smaller specific density.

Clayey-type materials in WFS resulted in a decrease in fluidity and the slump test values of concrete when used to replace sand. The void index showed a quite constant trend until $10 \%$ of foundry sand content and it rapidly decreased beyond that threshold [80]. The density values were not highly affected by the replacement percentage, aligned to other by products used as fine aggregates [81]. The replacement of sand with GGBFS as fine aggregate improved the workability of concrete mixture: the slump test result moved from $150 \mathrm{~mm}$ of a conventional paste to $180 \mathrm{~mm}$. This result may be caused by an increase in porosity: data reported by Valcuende et al. [92] show a proportional increase in porosity with the replacement level.

Concretes incorporating lead slag have shown a higher density compared to $\mathrm{RC}$ as a result of the high density of the slag itself [86]. At the same time, the addition of lead slag reduced the workability: samples analysed showed a lower slump than conventional concrete. The cause of this reduction is the use of finer materials "with more angular shapes" [93]. 
The substitution of coarse aggregates with electric arc furnace dust (EAFD) have led to a decrease in the initial workability [88]. This was a consequence of the higher water absorption: the investigations carried out by Arribas et al. [89] confirmed that the performance of concrete is caused by the porosity that increases with the share of EAFD, reaching $11.9 \%$. Density of final composites, however, does not highly differ from RC [87]. Artificial aggregates made out of GGBFS showed an analogous behaviour causing a high water absorption and a lower workability in concretes [94]. The lower bulk density of GGBFS coarse aggregates influenced also the density of fresh and hardened concrete: the difference between test samples and reference was around 3\% [91].

\subsubsection{Mechanical Properties}

Research showed different results in terms of compressive strength when WFS is used as fine aggregate: Khatib et al. [28] detected a "systematic decrease in compressive strength as the amount of WFS in concrete is increased", while according to results presented by Siddique and Singh [80] "there was marginal increase in the compressive strength". Different tests and investigations, instead, confirmed the low but positive impact of the substitution on the other mechanical properties like the flexural and tensile strength or the modulus of elasticity [80,95].

The replacement of fine aggregates with GGBFS has shown us how to enhance the overall mechanical performance of concrete: the compressive strength raised about $7.8 \%$ if compared to RC, and the effect of GGBFS increased up to $20 \%$ with a lower water-to-cement ratio. A similar trend has been detected by Teng et al. [96] in terms of both flexural strength, which raised of $7.5 \%$ with the addition of slag and modulus of elasticity. Even the effect of lead slag as fine aggregate on the mechanical properties of concretes varies in different research: according to Mosavinezhad et al. [93], results of the compressive strength of lead slag specimens at 28 days of curing "was $1 \%$ lower than those of the conventional concretes". Investigations carried out by Alwaeli [86], instead, recommend an increase in the compressive strength between $20-40 \%$ with a target of $37.8 \mathrm{MPa}$. The flexural strength resulted slightly lower than ordinary concrete at 28 days, but the difference increased in the long term [93].

Concretes that integrate EAFD slag as coarse aggregate represent an exception, as they showed a higher compressive strength than RC due to the rough texture of aggregate surface, but an increase in waste addition led to lower values in terms of both tensile strength and modulus of elasticity [88]. On the opposite, Coppola et al. [87] results recommend a slight increase in flexural and splitting tensile strength, caused by the rough texture of EAFD aggregates and "the improvement of the transition zone at the interface of the aggregate and the cement matrix". The higher water absorption caused another side effect as the shrinkage worsened by $30 \%$ with $25 \%$ of substitution.

The use of GGBFS, instead, led to a reduction in compressive strength up to $20.6 \%$ if compared to $\mathrm{RC}$ samples. The effect is caused by the lower compressive strength of slag aggregates than natural coarse aggregates, $100 \mathrm{MPa}$ to $200 \mathrm{MPa}$, respectively [91]. The splitting tensile strength followed the same trend, with a percentage reduction in $17.4 \%, 8.2 \%$, and $15.6 \%$ compared to RC, between $20 \%$ and $60 \%$ of replacement. The modulus of elasticity showed a similar behaviour, with an average decrease in $30 \%$ [97].

\subsubsection{Environmental Properties}

EAFD showed the best performance in terms of environmental compatibility as the results of leaching tests on the release of heavy metals complied with the threshold set by the legislation. The high concentration of chromium of GGBFS samples, instead, made them the less suitable alternative.

Tests conducted by Basar et al. [81] highlighted an increasing water absorption ratio with the addition of foundry sand: this trend align with the loss of compressive strength detected in some studies. The water absorption ratio of analysed specimens did not overcome $6 \%$ for $20 \%$ replacement ratio. As the detected heavy metal concentrations of the mixtures with different foundry sand content were compatible with standard limits, no adverse environmental effects have been associated with the 
use of this kind of concrete. Compared to RC, samples with the integration of GGBFS have shown an improvement in resistance against chloride penetration as both chloride migration coefficient and chloride permeability reached lower values. In fact, the classification of resistance to chloride penetration moved from "moderate" to "high" and "extremely high", while chloride permeability moved from "moderate" to "low". The addition of lead slag at 28 days decreased the water absorption of concrete, that moved from $3.49 \%$ of standard specimen to $2.52 \%$ : although, long-term performance of lead slag concrete exceeded the ordinary value [93].

According to the sorptivity test made by Etxeberria et al. [88], 25\% and 50\% EAFD concretes were the most absorbent materials. These results attested the low water transmit by capillarity of these concretes. As a consequence, the leaching of heavy metals remains very low and conformed to legal standards [98]. GGBFS contains a high share of chromium that could cause environmental pollution issues during the usage and disposal life cycle steps. The results of leaching under standard TCLP test conditions showed a high concentration of chromium often exceeding the regulatory norms [99]. 
Table 3. Physical, mechanical, and environmental performance of concrete products with alternative aggregates from metallurgical industry by-products.

\begin{tabular}{|c|c|c|c|c|c|c|c|c|}
\hline Aggregate & Property Class & $\begin{array}{l}\text { Substitute } \\
\text { By-Product }\end{array}$ & Property & $\begin{array}{l}\text { Replacement } \\
\text { Level }\end{array}$ & Value & $\begin{array}{c}\text { Unit of } \\
\text { Measurement }\end{array}$ & $\begin{array}{c}\text { Cement Type } \\
\text { (Water-to-Cement Ratio) }\end{array}$ & References \\
\hline \multirow{17}{*}{$\begin{array}{c}\text { Fine } \\
\text { aggregates }\end{array}$} & \multirow{9}{*}{$\begin{array}{l}\text { Physical } \\
\text { properties }\end{array}$} & \multirow{5}{*}{ Foundry sand } & Density & $10-40 \%$ & $2361-2410$ & $\mathrm{~kg} / \mathrm{m}^{3}$ & $\begin{array}{c}\text { OPC }(0.28-0.35) \\
\text { Portland pozzolana } \\
\text { FA-based cement } \\
(0.4-0.5)\end{array}$ & {$[80,94,99]$} \\
\hline & & & Slump test & $5-15 \%$ & $60-150$ & $\mathrm{~mm}$ & $\begin{array}{c}\text { PC CEM I 42.5R } \\
(0.45-0.53) \\
\text { Portland pozzolana } \\
\text { FA-based cement } \\
(0.4-0.5)\end{array}$ & {$[79,94,99]$} \\
\hline & & & Initial setting time & \multirow{2}{*}{$10-40 \%$} & $270-310$ & \multirow{2}{*}{$\min$} & \multirow{3}{*}{$\begin{array}{l}\text { PC CEM I 42.5R } \\
(0.45-0.53)\end{array}$} & \multirow{2}{*}{ [81] } \\
\hline & & & Final setting time & & $4500-4800$ & & & \\
\hline & & & Void index ${ }^{1}$ & $5-15 \%$ & $5.6-5.9$ & $\%$ & & {$[80]$} \\
\hline & & \multirow{2}{*}{ GGBFS } & Slump test ${ }^{2}$ & $30 \%$ & 180 & $\mathrm{~mm}$ & \multirow{2}{*}{$\begin{array}{c}\text { PC CEM II/B-M (S-L) } \\
42.5 \mathrm{R}(0.55)\end{array}$} & \multirow{2}{*}[92,96]{} \\
\hline & & & Porosity & $10-60 \%$ & $13.51-14.57$ & $\%$ & & \\
\hline & & \multirow{2}{*}{ Lead slag } & Density & $25-100 \%$ & $2210-2560$ & $\mathrm{~kg} / \mathrm{m}^{3}$ & \multirow{2}{*}{ Pozzolanic PC (0.4) } & {$[86,93]$} \\
\hline & & & Slump test & $30 \%$ & 75 & $\mathrm{~mm}$ & & [93] \\
\hline & \multirow{8}{*}{$\begin{array}{l}\text { Mechanical } \\
\text { properties }\end{array}$} & \multirow{4}{*}{ Foundry sand } & Compressive strength $(\mathrm{RC})^{3}$ & $30-100 \%$ & $\begin{array}{l}19-33(40) \\
29-30(28)\end{array}$ & \multirow{3}{*}{$\mathrm{MPa}$} & $\begin{array}{c}\text { PC CEM I } 42.5 \mathrm{R} \\
(0.45-0.53) \\
\text { Portland pozzolana } \\
\text { FA-based cement }\end{array}$ & {$[27,79,94,100]$} \\
\hline & & & Flexural strength $(\mathrm{RC})^{3}$ & $10-30 \%$ & $3.4-3.7(3.3)$ & & \multirow{3}{*}{43 grade OPC (0.5) } & {$[80,95]$} \\
\hline & & & Tensile strength (RC) ${ }^{3}$ & $5-20 \%$ & $2.8-3(2.7)$ & & & {$[80,95]$} \\
\hline & & & Modulus of elasticity (RC) ${ }^{3}$ & $10-30 \%$ & $\begin{array}{c}27-28(25) \\
30.5-31.5(30)\end{array}$ & GPa & & {$[80,95]$} \\
\hline & & \multirow{3}{*}{ GGBFS } & Compressive strength $(\mathrm{RC})^{3}$ & $\begin{array}{c}10-50 \% \\
30 \%\end{array}$ & $\begin{array}{l}42-52(52) \\
82.5(76.5)\end{array}$ & \multirow{2}{*}{$\mathrm{MPa}$} & 43 grade OPC (0.4-0.44) & {$[83,92,96]$} \\
\hline & & & Flexural strength (RC) ${ }^{3}$ & $30 \%$ & $7.2(6.7)$ & & \multirow{2}{*}{ OPC (0.28-0.35) } & \multirow{2}{*}{ [96] } \\
\hline & & & Modulus of elasticity $(\mathrm{RC})^{3}$ & & $3.64(3.07)$ & GPa & & \\
\hline & & Lead slag & Compressive strength $(\mathrm{RC})^{3}$ & $\begin{array}{c}25-100 \% \\
30 \%\end{array}$ & $\begin{array}{l}40-50(37.8) \\
18(18)\end{array}$ & $\mathrm{MPa}$ & $\begin{array}{c}\text { Limestone PCCEM } \\
\text { II/A-LL 42.5R (0.54) } \\
\text { ASTM Type I PC } \\
(0.29-0.58)\end{array}$ & {$[84,85,92]$} \\
\hline
\end{tabular}


Table 3. Cont

\begin{tabular}{|c|c|c|c|c|c|c|c|c|}
\hline Aggregate & Property Class & $\begin{array}{l}\text { Substitute } \\
\text { By-Product }\end{array}$ & Property & $\begin{array}{l}\text { Replacement } \\
\text { Level }\end{array}$ & Value & $\begin{array}{c}\text { Unit of } \\
\text { Measurement }\end{array}$ & $\begin{array}{c}\text { Cement Type } \\
\text { (Water-to-Cement Ratio) }\end{array}$ & References \\
\hline & & & Flexural strength (RC) ${ }^{3}$ & $30 \%$ & $0.9(1)$ & & 43 grade OPC (0.4-0.44) & [93] \\
\hline & \multirow{7}{*}{$\begin{array}{l}\text { Environmental } \\
\text { properties }\end{array}$} & \multirow{4}{*}{ Foundry sand } & \multirow{2}{*}{ Release of pollutants ${ }^{4}$} & \multirow{2}{*}{$10-40 \%$} & $0.013-0.022$ & $\mathrm{mg} \mathrm{Zn/L}$ & \multirow{3}{*}{$\begin{array}{l}\text { PC CEM I 42.5R } \\
(0.45-0.53)\end{array}$} & \multirow[b]{2}{*}[81]{} \\
\hline & & & & & $0.029-0.039$ & $\mathrm{mg} \mathrm{Cr} / \mathrm{L}$ & & \\
\hline & & & Water absorption ${ }^{3}$ & $5-15 \%$ & $2.4-2.5$ & $\%$ & & {$[80,81]$} \\
\hline & & & Chloride Permeability $^{3}$ & $5-20 \%$ & $1060-1250$ & $\mathrm{C}$ & $\begin{array}{l}\text { Portland pozzolana } \\
\text { FA-based cement } \\
(0.4-0.5)\end{array}$ & {$[100,101]$} \\
\hline & & \multirow{2}{*}{ GGBFS } & Chloride migration coefficient ${ }^{3}$ & \multirow{3}{*}{$30 \%$} & $7.92 \times 10^{-12}$ & $\mathrm{~m}^{2} / \mathrm{s}$ & \multirow[b]{2}{*}{ OPC (0.28-0.35) } & \multirow[b]{2}{*}{ [96] } \\
\hline & & & Chloride permeability ${ }^{3}$ & & 2097 & $\mathrm{C}$ & & \\
\hline & & Lead slag & Water absorption & & 2.52 & $\%$ & 43 grade OPC $(0.4-0.44)$ & [93] \\
\hline \multirow{5}{*}{$\begin{array}{c}\text { Coarse } \\
\text { aggregates }\end{array}$} & \multirow{5}{*}{$\begin{array}{l}\text { Physical } \\
\text { properties }\end{array}$} & \multirow{3}{*}{ EAFD } & Density & $10-25 \%$ & $2435-2500$ & $\mathrm{~kg} / \mathrm{m}^{3}$ & $\begin{array}{c}\text { Limestone Portland } \\
\text { Cement CE II/A-LL 42.5R } \\
(0.54)\end{array}$ & [87] \\
\hline & & & Slump & \multirow[t]{2}{*}{$100 \%$} & $55-90$ & $\mathrm{~mm}$ & $\begin{array}{c}\text { PC CEM I 52.5R } \\
(0.55-0.69) \\
\text { ASTM C150 Type I, PC } \\
(0.59 / 0.69) \\
\text { PC CEM II/A-LL 32.5R } \\
(0.43) \\
43 \text { grade OPC }(0.32)\end{array}$ & {$[86-88,101]$} \\
\hline & & & Porosity & & $10.1-11.9$ & $\%$ & $\begin{array}{c}\text { ASTM C150 Type I PC } \\
(0.59 / 0.69)\end{array}$ & [89] \\
\hline & & \multirow{2}{*}{ GGBFS } & Density & \multirow{2}{*}{$50-100 \%$} & 2309-2341 & $\mathrm{kg} / \mathrm{m}^{3}$ & $\begin{array}{l}\text { PC CEM II/A-LL 32.5R } \\
(0.43)\end{array}$ & [91] \\
\hline & & & Slump & & $150-175$ & $\mathrm{~mm}$ & $\begin{array}{l}\text { PC CEM II/B-M (S-L) } \\
\text { 42.5R (0.55) }\end{array}$ & {$[90,93,102]$} \\
\hline
\end{tabular}


Table 3. Cont

\begin{tabular}{|c|c|c|c|c|c|c|c|c|}
\hline Aggregate & Property Class & $\begin{array}{l}\text { Substitute } \\
\text { By-Product }\end{array}$ & Property & $\begin{array}{l}\text { Replacement } \\
\text { Level }\end{array}$ & Value & $\begin{array}{c}\text { Unit of } \\
\text { Measurement }\end{array}$ & $\begin{array}{c}\text { Cement Type } \\
\text { (Water-to-Cement Ratio) }\end{array}$ & References \\
\hline & \multirow{9}{*}{$\begin{array}{l}\text { Mechanical } \\
\text { properties }\end{array}$} & \multirow{5}{*}{ EAFD } & Compressive strength (RC) ${ }^{3}$ & \multirow{3}{*}{$25-100 \%$} & $55(40)$ & \multirow{3}{*}{$\mathrm{MPa}$} & $\begin{array}{c}\text { PC CEM I 52.5R } \\
(0.55-0.69) \\
\text { ASTM C150 Type I PC } \\
(0.59 / 0.69) \\
\text { PC CEM II/A-LL 32.5R } \\
(0.43) \\
43 \text { grade OPC }(0.32)\end{array}$ & {$[87-90,102]$} \\
\hline & & & Flexural strength $(\mathrm{RC})^{3}$ & & $8-9(9)$ & & $\begin{array}{c}\text { PC CEM II/A-LL 32.5R } \\
(0.43)\end{array}$ & [90] \\
\hline & & & Splitting tensile strength $(\mathrm{RC})^{3}$ & & $1.8-2.5(2.4)$ & & $\begin{array}{c}\text { Limestone PC CEM } \\
\text { II/A-LL 42.5R (0.54) } \\
\text { PC CEM I 52.5R } \\
(0.55-0.69)\end{array}$ & {$[87,88]$} \\
\hline & & & Shrinkage ${ }^{3}$ & $10-25 \%$ & $0.7-0.5$ & $\mathrm{~mm} / \mathrm{m}$ & $\begin{array}{l}\text { Limestone PC CEM } \\
\text { II/A-LL 42.5R }(0.54)\end{array}$ & {$[87,90]$} \\
\hline & & & Modulus of elasticity (RC) ${ }^{3}$ & $25-100 \%$ & $23.5-30.2(30.1)$ & $\mathrm{MPa}$ & $\begin{array}{c}\text { Limestone PC CEM } \\
\text { II/A-LL 42.5R (0.54) } \\
\text { ASTM C150 Type I PC } \\
(0.59 / 0.69)\end{array}$ & [87-89] \\
\hline & & \multirow{4}{*}{ GGBFS } & Compressive strength $(R C)^{3}$ & $20-100 \%$ & $43.1-47.9(55.8)$ & & \multirow{2}{*}{$\begin{array}{l}\text { PC CEM II/B-M (S-L) } \\
42.5 \mathrm{R}(0.5-0.6)\end{array}$} & \multirow{2}{*}[91,94,103]{} \\
\hline & & & & & $64.2-69.7(60.9)$ & & & \\
\hline & & & Splitting tensile strength $(\mathrm{RC})^{3}$ & $50-100 \%$ & $3.77-3.96(4.67)$ & & PC CEM U/A-LL 32.5R & \\
\hline & & & Modulus of elasticity $(\mathrm{RC})^{3}$ & & $27.4-28.8(34.6)$ & GPa & $(0.4-0.5)$ & {$[91,97]$} \\
\hline & \multirow{4}{*}{$\begin{array}{l}\text { Environmental } \\
\text { properties }\end{array}$} & \multirow{2}{*}{ EAFD } & Release of pollutants & $100 \%$ & 5.5 & $\mathrm{mg} \mathrm{Si} / \mathrm{L}$ & \multirow{2}{*}{$\begin{array}{c}\text { Limestone PC, } \\
\text { CEMII/A-L 42.5R } \\
(0.45-0.54)\end{array}$} & [98] \\
\hline & & & Sorptivity & $25-100 \%$ & $0.04-0.08$ & $\mathrm{~mm} / \mathrm{min}^{1 / 2}$ & & [88] \\
\hline & & \multirow[t]{2}{*}{ GGBFS } & Release of pollutants ${ }^{4}$ & $20-100 \%$ & $28-35$ & $\mathrm{mg} \mathrm{Cr} / \mathrm{L}$ & $\begin{array}{c}\text { OPC (0.5) } \\
\text { Blended Portland Slag } \\
\text { Cement }(0.5)\end{array}$ & [99] \\
\hline & & & $\mathrm{pH}$ & & $10.95-11.12$ & $\mathrm{mg} \mathrm{Cr} / \mathrm{L}$ & Portland Pozollana & \\
\hline
\end{tabular}

RC: reference concrete; MSWI: municipal solid waste incineration; ISSA: incinerator sewage sludge ash; GGBFS: ground granulated blast furnace slag; ASTM: American Society for Testing and Materials; OPC: ordinary portland cement; PC: Portland; CEM: cement. ${ }^{1}$ at 28 days; ${ }^{2}$ with $0.6 \%$ of superplasticizer; ${ }^{3}$ at 28 days; ${ }^{4}$ according to EN $12457-4$ with a pH of 5.5 ,

by Toxicity Characteristic Leaching Procedure test. 


\subsection{Other By-Products}

Coming from a completely different sector, mixed sheet glass is another kind of waste mainly disposed to landfill that can be recycled in concrete manufacturing. The substitution of natural sand and fine aggregates with sheet glass powder represents both an economical way to manage waste glass and a natural resources conservation strategy. With a replacement percentage around $10-20 \%$, the concrete performances are perfectly aligned with those containing natural sand aggregates [104]. In fact, the chemical composition and the pozzolanic properties of glass resemble those of sand [105]. Particle size mainly affects the concrete performance in bearing capacity and cohesion. A low particle size guarantees the pozzolanic reaction between the waste glass and the cement producing a higher resistance $[105,106]$. The decrease in the flexural strength of the final product in case of excessive waste glass addition is caused by a lower adhesion [107] due to the glass particle surface [108,109]. Recycled glass from bottles is another source for alternative fine aggregates. It decreases the water-cement ratio and the unit weight of concrete [110].

The possibility of using broken glass as a substitute for concrete coarse aggregate represents an alternative solution. Experiment have shown that recycled glass has a limit of $10 \%$ of replacement level in terms of weight in concrete mixtures: $5 \%$ weight incorporation presents a proper compressive strength result [111]. Properties related to alternative aggregates from other by-products are listed in Table 4.

Moving to other materials, an alternative substitute of fine aggregate in concrete is crumb rubber. Made from reprocessing of automobile tyres, crumb rubber can range from $0 \%$ to $100 \%$ in replacement of crushed sand in concrete mixtures. However, a $25 \%$ level guaranteed an acceptable compressive strength [112]. Concrete mix design based on pelletized cut rubber tyre particles have been tasted as an alternative mixture. The benefits of waste rubber incorporation account for more economical and cost-efficient final composites. Performance of such a concrete is not aligned with structural concrete requirements though, mainly because of the decrease in strength due to the weak bond between the rubber particles and the cement [113]. As in clinker production, Polyethylene terephthalate (PET) can also replace fine aggregates in a low range, around 5-6\%. The use of recycled PET bottle fibres increases compression and tensile strength of concrete composites and reduces the quantity of sand needed [114].

Even polyethylene terephthalate is a suitable alternative aggregate: plastic fibre aggregates are obtained by shredding, melting, and crushing the collected waste PET bottles. By increasing the PET replacement rate, a lower compressive strengths is observed, but proper performances are shown for a $20 \%$ ratio, with an higher workability than ordinary concrete [115].

\subsubsection{Physical Properties}

The smaller relative density of glass sand, if compared to natural fine aggregates, led to a lower density of the final composites. The fresh density was not affected by glass colour under $75 \%$ of replacement: at full substitution brown, green, clear, and mixed coloured glass sand concrete density reached $97 \%, 96 \%, 95 \%$, and $97 \%$ of that of $\mathrm{RC}$, respectively. The paste workability increased together with the share of glass powder added, but it decreased with the curing days. This effect is due to the alkali silica reaction.

Tests results have shown a linear relation between glass addition and unit weight, with a decrease in density for higher shares of glass. The decline has been attributed to the lower specific gravity of waste glass if compared to natural coarse aggregates [116]. Samples also showed a reduction in workability as a result of the slump tests.

\subsubsection{Mechanical Properties}

Glass powder registered a loss around $10-20 \%$ of both compressive and flexural resistance due to the particle size that can cause the cracking of the aggregate. At lower replacement levels, 
the use of glass sand instead of natural sand does not highly affect the mechanical performance of concrete: compressive, flexural, and tensile strength are close to RC under 10-15\% of substitution. Nevertheless, different research $[105,117,118]$ has shown that the alkali-silica reaction is responsible for cracking of aggregates during the production phase. The particle size has been proven to influence this process, as it increases with increasing the particle sizes of the waste glass aggregate. Therefore, compressive strength results lower, around $51 \%$ than $\mathrm{RC}$, when increasing the percentage of glass powder up to $60 \%$. A similar trend has been detected when investigating on the flexural strength: the reduction with an increasing percentage of the waste glass aggregate depends on the decrease in adhesive strength of glass particle surface $[104,105]$. Tensile strength, instead, showed the opposite behaviour increasing with the amount of glass used as fine aggregate [109].

Glass-based coarse aggregates cause a reduction in the overall mechanical performance of concrete: the compressive strength decreased around $26 \%$, due to the "smooth surface texture of these aggregates and poor bonding properties of the matrix". Sekar et al. [119] presented similar results in terms of tensile and flexural strength. Research has shown contradictory results concerning the modulus of elasticity: while some studies reported an increase in the modulus along with the replacement level [120,121], other investigations recommended a decrease around $40 \%$ [116]. A higher value of the modulus of elasticity can be explained by the finely divided waste glass that positively affects the bond properties.

\subsubsection{Environmental Properties}

Glass particle finesses and low porosity of specimens showed a positive effect increasing the resistance to chloride ion penetration. Concrete mixture integrating glass powder showed "no segregation or bleeding during mixing and casting" [105]. In terms of chloride permeability, all the mixtures with a range share of glass powder between $0-50 \%$ presented high values: the highest, 6764 Coulombs, in the case of natural sand. Glass colour affected this property as the charges passed with a 50\% replacement level for brown, green, clear, and mixed glass sand were $93 \%, 69 \%, 71 \%$, and $64 \%$, respectively. The lower porosity and the finer size of glass particles integrated in concrete have positively affected the resistance to chloride ion penetration. Regarding sulphate attack, the different mixtures registered comparable weight loss [109].

The use of glass aggregate in concrete has led to a higher concentration of $\mathrm{Pb}$ as underlined by Synthetic Precipitation Leaching Procedure tests carried out by Romero et al. [122]. The performance must be more deeply investigated in order to evaluate the properties referred to a monolithic specimen, which are most influenced by diffusion. 
Table 4. Physical, mechanical, and environmental performance of concrete products with alternative aggregates from other by-products.

\begin{tabular}{|c|c|c|c|c|c|c|c|c|}
\hline Aggregate & Property Class & $\begin{array}{l}\text { Substitute } \\
\text { By-Product }\end{array}$ & Property & $\begin{array}{l}\text { Replacement } \\
\text { Level }\end{array}$ & Value & $\begin{array}{c}\text { Unit of } \\
\text { Measurement }\end{array}$ & $\begin{array}{c}\text { Cement Type } \\
\text { (Water-to-Cement Ratio) }\end{array}$ & References \\
\hline \multirow{10}{*}{$\begin{array}{c}\text { Fine } \\
\text { aggregates }\end{array}$} & \multirow{4}{*}{$\begin{array}{l}\text { Physical } \\
\text { properties }\end{array}$} & \multirow{10}{*}{ Glass } & Relative density & $10-50 \%$ & $3.14-3.27$ & & $\begin{array}{c}\text { PC CEM II/B-M (S-L) } \\
42.5 \mathrm{R}(0.5-0.6)\end{array}$ & [104] \\
\hline & & & Fresh density & $25-100 \%$ & $2220-2110$ & $\mathrm{~kg} / \mathrm{m}^{3}$ & $\begin{array}{c}\text { ASTM Type I PC } \\
(0.47-0.485)\end{array}$ & [109] \\
\hline & & & Porosity & $10-50 \%$ & $33-35$ & $\%$ & $\begin{array}{c}\text { PC CEM II/B-M (S-L) } \\
42.5 \mathrm{R}(0.5-0.6)\end{array}$ & [104] \\
\hline & & & Thermal conductivity & $15-45 \%$ & $0.1-0.18$ & $\mathrm{~W} /(\mathrm{m} \mathrm{K})$ & OPC (0.4-0.5) & [123] \\
\hline & \multirow{4}{*}{$\begin{array}{l}\text { Mechanical } \\
\text { properties }\end{array}$} & & Compressive strength (RC) ${ }^{1}$ & $\begin{array}{c}10-50 \% \\
25-100 \%\end{array}$ & $\begin{array}{l}35-40(40) \\
34-54(52)\end{array}$ & \multirow{3}{*}{$\mathrm{MPa}$} & \multirow{3}{*}{ OPC (0.5-0.6) } & {$[103,104,108]$} \\
\hline & & & Flexural strength (RC) ${ }^{1}$ & \multirow{2}{*}{$10-50 \%$} & $5-7(7)$ & & & \multirow{2}{*}[104,109]{} \\
\hline & & & Tensile strength (RC) ${ }^{1}$ & & $6-10(7)$ & & & \\
\hline & & & Modulus of elasticity (RC) ${ }^{2}$ & $25-100 \%$ & $23-29(30)$ & $\mathrm{GPa}$ & \multirow{3}{*}{$\begin{array}{c}\text { ASTM Type I PC } \\
(0.47-0.485)\end{array}$} & \multirow{3}{*}{ [109] } \\
\hline & \multirow{2}{*}{$\begin{array}{c}\text { Environmental } \\
\text { properties }\end{array}$} & & Chloride permeability ${ }^{3}$ & \multirow{2}{*}{$25-100 \%$} & $2500-6200$ & $\mathrm{C}$ & & \\
\hline & & & Sulphate attack (weight loss \%) & & $4.5-5$ & $\%$ & & \\
\hline \multirow{8}{*}{$\begin{array}{c}\text { Coarse } \\
\text { aggregates }\end{array}$} & \multirow{2}{*}{$\begin{array}{l}\text { Physical } \\
\text { properties }\end{array}$} & \multirow{8}{*}{ Glass } & Density & $5-40 \%$ & $2330-2340$ & $\mathrm{~kg} / \mathrm{m}^{3}$ & $\begin{array}{c}\text { Compose PKÇ/B 32.5R } \\
(0.54)\end{array}$ & [116] \\
\hline & & & Slump & & $10-89$ & $\mathrm{~mm}$ & 43 grade OPC $(0.5-0.6)$ & {$[116,124]$} \\
\hline & \multirow{4}{*}{$\begin{array}{l}\text { Mechanical } \\
\text { properties }\end{array}$} & & Compressive strength $(\mathrm{RC})^{3}$ & $5-40 \%$ & $13.2-20.6(19.3)$ & \multirow{3}{*}{$\mathrm{MPa}$} & & {$[116,119,124,125]$} \\
\hline & & & Flexural strength (RC) ${ }^{3}$ & $40 \%$ & $13.94(17.13)$ & & \multirow{2}{*}{43 grade OPC $(0.5-0.6)$} & \multirow{2}{*}[116,119]{} \\
\hline & & & Splitting tensile strength $(\mathrm{RC})^{3}$ & $40 \%$ & $2.94(3.24)$ & & & \\
\hline & & & Modulus of elasticity $(\mathrm{RC})^{3}$ & $5-40 \%$ & $50-22(59.9)$ & $\mathrm{GPa}$ & $\begin{array}{c}\text { Compose PKÇ/B 32.5R } \\
(0.54)\end{array}$ & [116] \\
\hline & \multirow{2}{*}{$\begin{array}{c}\text { Environmental } \\
\text { properties }\end{array}$} & & Release of pollutants ${ }^{4}$ & $5-40 \%$ & $0.016-0.132$ & $\mathrm{mg} \mathrm{Pb} / \mathrm{L}$ & \multirow{2}{*}{ OPC $(0.4-0.6)$} & \multirow{2}{*}{ [122] } \\
\hline & & & Release of pollutants & $10-30 \%$ & $0.5-100^{5}$ & $\mathrm{mg} \mathrm{Pb} / \mathrm{L}$ & & \\
\hline
\end{tabular}

RC: reference concrete; MSWI: municipal solid waste incineration; ISSA: incinerator sewage sludge ash; GGBFS: ground granulated blast furnace slag; EAFD: electric arc furnace dust; ASTM: American Society for Testing and Materials; OPC: ordinary portland cement; PC: Portland; CEM: cement. ${ }^{1}$ at 28 days; ${ }^{2}$ static; ${ }^{3}$ at 28 days; ${ }^{4}$ by Synthetic Precipitation Leaching Procedure test; ${ }^{5}$ the release is strongly dependent on the $\mathrm{pH}$ value. 


\section{Discussion}

The increasing urbanization is leading to a massive production of concrete, thus of aggregates, with a dangerous effect on non-renewable natural resources, such as river sand and limestone, due to an increasing extraction rate [126]. Even if the building industry is the second largest in generating waste, with construction sector responsible for around $30 \%$ of the waste produced, recycled aggregates only represent the $3 \%$ of the total demand [127]. Recent research has focused on possible applications of recycled aggregates to suitably replace natural ones in creating sustainable concrete, checking mechanical properties, durability, environmental impact, and cost [128].

In this framework, determining the properties of final products that integrate alternative aggregates is an essential step to define their suitability in civil applications. Table 5 summarizes the results of the main alternative aggregates among those investigated, resuming some of the most relevant properties for each element analysed. Even if determining the best alternative aggregate is not possible as the mixtures investigated present different proportions and binders, general trends can be outlined. Regarding physical properties, all the alternative aggregates show density values close to reference ones, with the exception of recycled coarse aggregate and MSWI ash-based fine aggregates, which were characterized by low density values, mainly due to the quality of the original waste. Incorporation of waste and discards generally led to a decrease in the workability and density, as artificial recycled products usually showed lower density and pozzolanic activity than natural aggregates. Concerning the workability, GGBFS aggregates had a positive impact on hardened samples, with $180 \mathrm{~mm}$ of slump, due to the increased porosity. Regarding the mechanical resistance, ceramic showed the better overall performance, increasing the compressive, flexural, and tensile strength, compared to the target of the reference concrete. Other alternatives reduce the mechanical performance, with MSWI ash, ISSA, and glass recording the worst behaviour. The substitution of coarse aggregate, in fact, usually led to a decrease in the overall resistance, due to the poorer properties of artificial aggregates compared to natural ones, except for EAFD. Fine aggregates replacement, instead, enhanced the performance around $10-20 \%$, with EAFD and ceramic waste showing the best improvement. Looking at the environmental compatibility of alternative aggregates, generally the resistance to chloride ion penetration improves, while pollutant release depends on the kind of waste used: it is related to metallurgical by-products, that mainly affect $\mathrm{Cr}, \mathrm{Pb}$, and $\mathrm{Si}$ release. Construction and demolition wastes, as products already used in buildings, usually complied with the legislation thresholds, while residues from waste treatment and metallurgical industry as a substitute for fine aggregates exceeded the maximum values allowed for construction application, both in the case of lead slag and MSWI ash. Globally, ceramic represent the alternative aggregate with the highest potential, both for fine and coarse aggregates, while MSWI ash-based aggregates determine a relevant loss in both the physical and mechanical performance of concrete.

The present work has focused on the properties of the final products that integrate alternative aggregates coming from four main waste streams not considering the properties of alternative materials themselves. International legislation and national regulations, nevertheless, define limits and set a minimum performance that materials must answer to before they could be used in concrete production [65]. The properties of aggregates are set by the UNI EN 12620, which defines chemical, physical, and geometric properties. The range in the performance value mainly depends on two influencing factors: the replacement level and the mixture components or proportion. The replacement level influences the performance linearly with the quality of alternative product: the integration of recycled aggregates, for example, that show lower properties and quality than conventional ones impacts on final product according to the substitution rate. As the data collected state, the substitution rates are lower for fine aggregates if compared to coarse ones: this underlines the higher impact that fine aggregates substitution has on final product compared to coarse ones, as they influence cohesion and resistance of the mixture. As ordinary concrete, the range of values is linked to the water-to-binder ratio used in each specific research activity and the kind of cement, mainly Portland, whose composition interacts differently with alternative aggregates. 
Table 5. Physical, mechanical, and environmental performance of concrete products with alternative aggregates.

\begin{tabular}{|c|c|c|c|c|c|c|}
\hline \multirow[b]{2}{*}{ Waste Stream } & \multirow{2}{*}{$\begin{array}{l}\text { Substitute } \\
\text { By-Product }\end{array}$} & \multirow{2}{*}{ Property Class } & \multirow{2}{*}{ Property } & \multicolumn{2}{|c|}{ Value } & \multirow{2}{*}{$\begin{array}{c}\text { Unit of } \\
\text { Measurement }\end{array}$} \\
\hline & & & & $\begin{array}{c}\text { Fine Aggregate } \\
\text { [Replacement Level] }\end{array}$ & $\begin{array}{c}\text { Coarse Aggregate } \\
\text { [Replacement Level] }\end{array}$ & \\
\hline \multirow{14}{*}{$\begin{array}{l}\text { Construction and } \\
\text { demolition wastes }\end{array}$} & \multirow{7}{*}{ Ceramic } & Physical properties & Density & $2179-2184[15-50 \%]$ & $2190-2430[20-100 \%]$ & $\mathrm{kg} / \mathrm{m}^{3}$ \\
\hline & & \multirow{3}{*}{$\begin{array}{l}\text { Mechanical } \\
\text { properties }\end{array}$} & Compressive strength (RC) & $\begin{array}{c}33.7-35.7(33) \\
{[50-100 \%]}\end{array}$ & $\begin{array}{c}25.7-28.2(26.9) \\
{[20-100 \%]}\end{array}$ & \multirow{3}{*}{$\mathrm{MPa}$} \\
\hline & & & Flexural strength $(\mathrm{RC})$ & $\begin{array}{c}6.55-8.31(6.47) \\
{[50-100 \%]}\end{array}$ & $\begin{array}{c}4.7-6.9(5-7) \\
{[20-100 \%]}\end{array}$ & \\
\hline & & & Tensile strength (RC) & $\begin{array}{c}5.14-5.25(5.13) \\
{[50-100 \%]}\end{array}$ & $\begin{array}{c}4.2-4.6(5.13) \\
{[20-100 \%]}\end{array}$ & \\
\hline & & \multirow{3}{*}{$\begin{array}{l}\text { Environmental } \\
\text { properties }\end{array}$} & Absorption capacity & $\begin{array}{c}1.3 \\
{[50-100 \%]}\end{array}$ & $\begin{array}{c}1.88-3.97 \\
{[20-100 \%]}\end{array}$ & $\%$ \\
\hline & & & Water permeability & $\begin{array}{c}5-6 \times 10^{-17} \\
{[50-100 \%]}\end{array}$ & $\begin{array}{c}6 \times 10^{-17} \\
{[50 \%]}\end{array}$ & $\mathrm{m}^{2}$ \\
\hline & & & Chloride-ion penetration & $\begin{array}{c}1000 \\
{[50-100 \%]}\end{array}$ & $\begin{array}{l}1100-1600 \\
{[20-100 \%]}\end{array}$ & $\mathrm{C}$ \\
\hline & \multirow{7}{*}{ Recycled Aggregates } & Physical properties & Density & - & $\begin{array}{l}1800-1970 \\
{[10-100 \%]}\end{array}$ & $\mathrm{kg} / \mathrm{m}^{3}$ \\
\hline & & \multirow{3}{*}{$\begin{array}{l}\text { Mechanical } \\
\text { properties }\end{array}$} & Compressive strength (RC) & - & $\begin{array}{l}20-27(17) \\
{[10-100 \%]}\end{array}$ & \multirow{3}{*}{$\mathrm{MPa}$} \\
\hline & & & Flexural strength $(\mathrm{RC})$ & - & $\begin{array}{l}4.3-4.5(4.4) \\
{[10-100 \%]}\end{array}$ & \\
\hline & & & Tensile strength $(\mathrm{RC})$ & - & $\begin{array}{c}2.6(3.1) \\
{[10-100 \%]}\end{array}$ & \\
\hline & & \multirow{3}{*}{$\begin{array}{l}\text { Environmental } \\
\text { properties }\end{array}$} & \multirow{3}{*}{ Release of pollutants } & - & 0.18 & $\mathrm{mg} \mathrm{Cr} / \mathrm{kg}$ \\
\hline & & & & - & 0.007 & $\mathrm{mg} \mathrm{Zn/kg}$ \\
\hline & & & & - & 0.011 & $\mathrm{mg} \mathrm{As} / \mathrm{kg}$ \\
\hline
\end{tabular}


Table 5. Cont.

\begin{tabular}{|c|c|c|c|c|c|c|}
\hline \multirow{2}{*}{ Waste Stream } & \multirow{2}{*}{$\begin{array}{l}\text { Substitute } \\
\text { By-Product }\end{array}$} & \multirow{2}{*}{ Property Class } & \multirow{2}{*}{ Property } & \multicolumn{2}{|c|}{ Value } & \multirow{2}{*}{$\begin{array}{c}\text { Unit of } \\
\text { Measurement }\end{array}$} \\
\hline & & & & $\begin{array}{c}\text { Fine Aggregate } \\
\text { [Replacement Level] }\end{array}$ & $\begin{array}{c}\text { Coarse Aggregate } \\
\text { [Replacement Level] }\end{array}$ & \\
\hline \multirow{8}{*}{$\begin{array}{c}\text { Residues from waste } \\
\text { treatment }\end{array}$} & \multirow{4}{*}{ MSWIAsh } & Physical properties & Density & $\begin{array}{c}1630 \\
{[40 \%]}\end{array}$ & $2295-2331$ & $\mathrm{~kg} / \mathrm{m}^{3}$ \\
\hline & & Mechanical & Compressive strength (RC) & $\begin{array}{l}65-75(87) \\
{[10-30 \%]}\end{array}$ & $\begin{array}{c}2-4.5(5) \\
{[60-90 \%]}\end{array}$ & \multirow{2}{*}{$\mathrm{MPa}$} \\
\hline & & properties & Flexural strength (RC) & $\begin{array}{c}11-11.5(12) \\
{[10-30 \%]}\end{array}$ & $\begin{array}{l}5.8-6.4(6.7) \\
{[10-100 \%]}\end{array}$ & \\
\hline & & $\begin{array}{l}\text { Environmental } \\
\text { properties }\end{array}$ & Release of pollutants & $0.16-0.26$ & $\begin{array}{c}5-11 \\
{[60-90 \%]}\end{array}$ & $\mathrm{mg} \mathrm{Cr} / \mathrm{L}$ \\
\hline & \multirow{4}{*}{ ISSA } & Physical properties & Density & $\begin{array}{c}2100-2200 \\
{[5-20 \%]}\end{array}$ & - & $\mathrm{kg} / \mathrm{m}^{3}$ \\
\hline & & \multirow{2}{*}{$\begin{array}{l}\text { Mechanical } \\
\text { properties }\end{array}$} & Compressive strength (RC) & $\begin{array}{c}24-33(32) \\
{[5-20 \%]}\end{array}$ & - & \multirow{2}{*}{$\mathrm{MPa}$} \\
\hline & & & Flexural strength (RC) & $\begin{array}{c}3.5-4.5(5) \\
{[5-20 \%]}\end{array}$ & - & \\
\hline & & $\begin{array}{l}\text { Environmental } \\
\text { properties }\end{array}$ & Water absorption & $\begin{array}{c}4.19-4.38 \\
{[5-10 \%]}\end{array}$ & - & $\%$ \\
\hline \multirow{9}{*}{$\begin{array}{c}\text { Metallurgical } \\
\text { industry by-products }\end{array}$} & \multirow{6}{*}{ GGBFS } & Physical properties & Density & - & $2309-2341$ & $\mathrm{~kg} / \mathrm{m}^{3}$ \\
\hline & & \multirow{3}{*}{$\begin{array}{l}\text { Mechanical } \\
\text { properties }\end{array}$} & Compressive strength & $\begin{array}{l}42-52(52) \\
{[10-50 \%]}\end{array}$ & $\begin{array}{c}20.3-24.1(22) \\
{[25-100 \%]}\end{array}$ & \multirow{3}{*}{$\mathrm{MPa}$} \\
\hline & & & Flexural strength $(\mathrm{RC})$ & $\begin{array}{c}7.2(6.7) \\
{[30 \%]}\end{array}$ & - & \\
\hline & & & Splitting tensile strength (RC) & - & $\begin{array}{c}3.77-3.96(4.67) \\
{[50-100 \%]}\end{array}$ & \\
\hline & & \multirow{2}{*}{$\begin{array}{c}\text { Environmental } \\
\text { properties }\end{array}$} & Chloride permeability & 2097 & - & $\mathrm{C}$ \\
\hline & & & Release of pollutants & - & $28-35$ & $\mathrm{mg} \mathrm{Cr} / \mathrm{L}$ \\
\hline & \multirow{3}{*}{ Foundry sand } & Physical properties & Density & $\begin{array}{c}2361-2410 \\
{[10-40 \%]}\end{array}$ & - & $\mathrm{kg} / \mathrm{m}^{3}$ \\
\hline & & \multirow{2}{*}{$\begin{array}{l}\text { Mechanical } \\
\text { properties }\end{array}$} & Compressive strength & $\begin{array}{l}19-33(40) \\
{[30-100 \%]}\end{array}$ & - & \multirow{2}{*}{$\mathrm{MPa}$} \\
\hline & & & Flexural strength (RC) & $\begin{array}{c}3.4-3.7(3.3) \\
{[10-30 \%]}\end{array}$ & - & \\
\hline
\end{tabular}


Table 5. Cont.

\begin{tabular}{|c|c|c|c|c|c|c|}
\hline \multirow{2}{*}{ Waste Stream } & \multirow{2}{*}{$\begin{array}{l}\text { Substitute } \\
\text { By-Product }\end{array}$} & \multirow{2}{*}{ Property Class } & \multirow{2}{*}{ Property } & \multicolumn{2}{|c|}{ Value } & \multirow{2}{*}{$\begin{array}{c}\text { Unit of } \\
\text { Measurement }\end{array}$} \\
\hline & & & & $\begin{array}{c}\text { Fine Aggregate } \\
\text { [Replacement Level] }\end{array}$ & $\begin{array}{c}\text { Coarse Aggregate } \\
\text { [Replacement Level] }\end{array}$ & \\
\hline & & & Tensile strength (RC) & $\begin{array}{c}2.8-3(2.7) \\
{[5-20 \%]}\end{array}$ & - & \\
\hline & & $\begin{array}{l}\text { Environmental } \\
\text { properties }\end{array}$ & Release of pollutants & $0.029-0.039$ & - & $\mathrm{mg} \mathrm{Cr} / \mathrm{L}$ \\
\hline & \multirow{5}{*}{ EAFD } & Physical properties & Density & - & $\begin{array}{c}2435-2500 \\
{[10-25 \%]}\end{array}$ & $\mathrm{kg} / \mathrm{m}^{3}$ \\
\hline & & & Compressive strength & - & $\begin{array}{c}55(40) \\
{[25-100 \%]}\end{array}$ & \multirow{3}{*}{$\mathrm{MPa}$} \\
\hline & & $\begin{array}{l}\text { Mechanical } \\
\text { properties }\end{array}$ & Flexural strength (RC) & - & $\begin{array}{c}8-9(9) \\
{[25-100 \%]}\end{array}$ & \\
\hline & & & Tensile strength (RC) & - & $\begin{array}{l}1.8-2.5(2.4) \\
{[25-100 \%]}\end{array}$ & \\
\hline & & $\begin{array}{l}\text { Environmental } \\
\text { properties }\end{array}$ & Release of pollutants & - & $\begin{array}{c}5.5 \\
{[100 \%]}\end{array}$ & $\mathrm{mg} \mathrm{Si} / \mathrm{L}$ \\
\hline \multirow{6}{*}{ Other by-products } & \multirow{6}{*}{ Glass } & Physical properties & Density & $\begin{array}{l}2220-2110 \\
{[25-100 \%]}\end{array}$ & $\begin{array}{c}2330-2340 \\
{[5-40 \%]}\end{array}$ & $\mathrm{kg} / \mathrm{m}^{3}$ \\
\hline & & \multirow{3}{*}{$\begin{array}{l}\text { Mechanical } \\
\text { properties }\end{array}$} & Compressive strength & $\begin{array}{l}34-54(52) \\
{[10-50 \%]}\end{array}$ & $\begin{array}{c}13.2-20.6(19.3) \\
{[5-40 \%]}\end{array}$ & \multirow{3}{*}{$\mathrm{MPa}$} \\
\hline & & & Flexural strength (RC) & $\begin{array}{c}5-7(7) \\
{[10-50 \%]}\end{array}$ & $\begin{array}{c}13.94(17.13) \\
{[40 \%]}\end{array}$ & \\
\hline & & & Tensile strength (RC) & $\begin{array}{c}6-10(7) \\
{[10-50 \%]}\end{array}$ & $\begin{array}{c}2.94(3.24) \\
{[40 \%]}\end{array}$ & \\
\hline & & \multirow[t]{2}{*}{$\begin{array}{l}\text { Environmental } \\
\text { properties }\end{array}$} & Chloride permeability & $\begin{array}{l}2500-6200 \\
{[25-100 \%]}\end{array}$ & - & $\mathrm{C}$ \\
\hline & & & Release of pollutants & - & $\begin{array}{c}0.016-0.132 \\
{[5-40 \%]}\end{array}$ & $\mathrm{mg} \mathrm{Pb} / \mathrm{L}$ \\
\hline
\end{tabular}


Looking to impact, research highlights the potential of reducing environmental footprint, mainly regarding the landfill use: a reduction between $6 \%$ and $8 \%$ and between $19 \%$ and $23 \%$ when $30 \%$ and $100 \%$ of fine aggregates are replaced [129].

The advantages of recycled aggregates rather than common ones in concrete result mainly in the terms of land use, when related to the exploitation of the quarry [130]. Various factors affect the magnitude of possible environmental impact of alternative materials, moving from the recycling process, and related embodied energies, to transportation: a linear correlation links the effect of alternative aggregates integration and the variation in transportation distances compared with natural aggregates. The unit contribution of aggregates to the total $\mathrm{CO}_{2}$ emissions is low, but it becomes relevant considering the amount of aggregate in the total concrete volume.

Turk et al. carried out an LCA analysis on samples made with (i) foundry sand, (ii) steel slag, and (iii) recycled aggregates from reinforced concrete waste: major common benefit was related to avoidance of the need to dispose of the waste materials, while extra credit came from the recovery of scrap iron from the steel reinforcement, in case of recycled aggregates, and from the recovery of metals, when dealing with steel slag. Research confirmed that the possible long delivery distance represents the main disadvantage. Results showed that fly ash and foundry sand, especially combined with recycled aggregates: a reduction in environmental impact around $75 \%, 85 \%$, and $95 \%$ has been detected for fly ash, foundry sands, and EAF slag, respectively. The last case showed a neglectable improvement of $\mathrm{CO}_{2}$ emissions, but a very significant impact with regard to Eutrophication [131]. Recycled aggregates proved to be less efficient in reducing greenhouse gas emissions [132].

\section{Conclusions}

To reduce concrete-related $\mathrm{CO}_{2}$ emissions, the integration of wastes and by-products as components in concrete production is a promising strategy: the magnitude of their effect, however, is strictly linked to the properties of the final product, which must comply with the requirements for common applications. The most relevant and investigated characteristics are mechanical properties and environmental compatibilities, particularly heavy metal release-related ones: a deeper investigation is needed on physical side as analysis mainly focuses on density and workability, since they have a direct relapse on the manufacturing process, but little information is available for acoustical and thermal properties. A proper thermal characterization of concretes with alternative aggregates would be significant even for the evaluation of fire resistance performance.

In conclusion, the aggregate substitution proved to have a high impact on properties: GGBFS showed the highest potential, with positive effects on workability as a fine aggregate substitute, along with EAFD and ceramic powder, which improved the durability and mechanical properties of concrete. Excluding quarry dust and ISSA for fine aggregates, and glass for coarse ones, generally aggregates can easily reach a complete replacement with other alternative materials, but high substitution rates commonly generate relevant side effects.

Author Contributions: Conceptualization, M.C.C., A.A. and P.R.; writing-original draft preparation, G.C., A.A. and M.C.M.; writing-review and editing, A.A., V.T. and E.C.R.; visualization and supervision, M.C.C. and P.R. All authors have read and agreed to the published version of the manuscript.

Funding: This research received no external funding.

Conflicts of Interest: The authors declare no conflict of interest.

\section{Abbreviations}

AITEC Italian Technical and Economic Cement Association

ANCE Italian Association of Building Contractors

ASTM American Society for Testing and Materials

ATECAP Italian Technical and Economic Association of Precast Concrete

BA bottom ash

BIBM European Federation for precast concrete 


$\begin{array}{ll}\text { CEM } & \text { cement } \\ \text { EAFD } & \text { electric arc furnace dust } \\ \text { ECRA } & \text { European Cement Research Academy } \\ \text { ERMCO } & \text { European Ready Mixed Concrete Organization } \\ \text { FA } & \text { fly ash } \\ \text { GCCA } & \text { Global Cement and Concrete Association } \\ \text { GGBFS } & \text { ground granulated blast furnace slag } \\ \text { GHG } & \text { greenhouse gas } \\ \text { IEA } & \text { International Energy Agency } \\ \text { ISSA } & \text { incinerator sewage sludge ash } \\ \text { MSWI } & \text { municipal solid waste incineration } \\ \text { OPC } & \text { ordinary Portland cement } \\ \text { PC } & \text { Portland cement } \\ \text { PET } & \text { polyethylene terephthalate } \\ \text { PVC } & \text { polyvinyl chloride } \\ \text { RC } & \text { reference concrete } \\ \text { SPLP } & \text { synthetic precipitation leaching procedure } \\ \text { SS } & \text { sewage sludge } \\ \text { TCLP } & \text { toxicity characteristic leaching procedure } \\ \text { WFS } & \text { waste foundry sand }\end{array}$

\section{References}

1. BIBM (Federation of the European Precast Concrete Industry). What is Concrete? Available online: https://bibm.eu/precast-concrete/what-is-concrete/ (accessed on 20 October 2019).

2. Puertas, F.; García-Díaz, I.; Barba, A.; Gazulla, M.F.; Palacios, M.; Gómez, M.P.; Martínez-Ramírez, S. Ceramic wastes as alternative raw materials for Portland cement clinker production. Cem. Concr. Compos. 2008, 30, 798-805. [CrossRef]

3. IEA (International Energy Agency). Cement-Tracking Clean Energy Progress; IEA: Paris, France, 2019. Available online: https://www.iea.org/reports/tracking-industry/cement (accessed on 6 March 2020).

4. Röck, M.; Saade, M.R.M.; Balouktsi, M.; Rasmussen, F.N.; Birgisdottir, H.; Frischknecht, R.; Habert, G.; Lützkendorf, T.; Passer, A. Embodied GHG emissions of buildings-The hidden challenge for effective climate change mitigation. Appl. Energy 2020, 258, 114107. [CrossRef]

5. Schneider, M.; Romer, M.; Tschudin, M.; Bolio, H. Sustainable cement production-Present and future. Cem. Concr. Res. 2011, 41, 642-650. [CrossRef]

6. UN. Sand and Sustainability: Finding New Solutions for Environmental Governance of Global Sand Resources; UN: New York, NY, USA, 2019.

7. Kuo, W.-T.; Gao, Z.-C. Engineering Properties of Controlled Low-Strength Materials Containing Bottom Ash of Municipal Solid Waste Incinerator and Water Filter Silt. Appl. Sci. 2018, 8, 1377. [CrossRef]

8. Jang, J.G.; Park, S.-M.; Chung, S.; Ahn, J.-W.; Kim, H.-K. Utilization of circulating fluidized bed combustion ash in producing controlled low-strength materials with cement or sodium carbonate as activator. Constr. Build. Mater. 2018, 159, 642-651. [CrossRef]

9. ATECAP (Technical and Econimic Association of Precast Concrete). Report 2019_Economical, Industrial and Specific Scenarios; ATECAP: Rome, Italy, 2019.

10. ERMCO (European Ready Mixed Concrete Organisation). Ready-Mixed Concrete Industry Statistics; ERMCO: Indianapolis, IN, USA, 2016.

11. ANCE (National Association of Construction Companies). Report on Building Italian Companies in the World; ANCE: Rome, Italy, 2018.

12. ANCE (National Association of Construction Companies). Observatory of Conjuncture on Construction Industry; ANCE: Rome, Italy, 2019.

13. UEPG (Union Européenne des Producteurs de Granulats). Current Trends for the European Aggregates Sector; UEPG: Brussels, Belgium, 2018. Available online: http://www.uepg.eu/statistics/current-trends (accessed on 15 November 2019). 
14. Ricciardi, P.; Cillari, G.; Carnevale Miino, M.; Collivignarelli, M.C. Valorization of agro-industry residues in the building and environmental sector: A review. Waste Manag. Res. 2020, 38, 487-513. [CrossRef]

15. Buratti, C.; Belloni, E.; Lascaro, E.; Lopez, G.A.; Ricciardi, P. Sustainable Panels with Recycled Materials for Building Applications: Environmental and Acoustic Characterization. Energy Procedia 2016, 101, 972-979. [CrossRef]

16. GCCA (Global Cement and Concrete Association). Sustainability Guidelines for the Monitoring and Reporting of $\mathrm{CO}_{2}$ Emissions from Cement Manufacturing; GCCA: Arlington, VA, USA, 2018.

17. UN (United Nations) Climate Action Summit 2019. Available online: https://www.un.org/en/climatechange/ un-climate-summit-2019.shtml (accessed on 31 October 2019).

18. AITEC (Italian Technical and Economical Cement Association). Sustainability Report; AITEC: Rome, Italy, 2018.

19. Federbeton. General Guidelines on the Concrete Thermal Mass Benefits and Its Exploitation in Building Construction; Federbeton: Rome, Italy, 2009.

20. TCI (The Concrete Initiative). The Role of Cement and Concrete in the Circular Economy; TCI: Brussels, Belgium, 2018. Available online: https://www.theconcreteinitiative.eu/?id=102:the-role-of-cement-and-concrete-inthe-circular-economy (accessed on 6 March 2020).

21. Kan, A.; Demirboğa, R. A novel material for lightweight concrete production. Cem. Concr. Compos. 2009, 31, 489-495. [CrossRef]

22. Rada, E.C.; Ragazzi, M.; Torretta, V.; Castagna, G.; Adami, L.; Cioca, L.I. Circular Economy and Waste to Energy; AIP Publishing LLC: Melville, NY, USA, 2018; p. 030050.

23. Rada, E.; Squazardo, L.; Ionescu, G.; Badea, A. Economic viability of srf co-combustion in cement factory. UPB Sci. Bull. Ser. D Mech. Eng. 2014, 76, 199-206.

24. ECRA (European Cement Research Academy). Technical Report; ECRA: Düsseldorf, Germany, 2015.

25. WSBCD (World Business Council for Sustainable Development). The Cement Sustainability Initiative: Our Agenda for Action; WSBCD: Geneva, Switzerland, 2002.

26. Smol, M.; Kulczycka, J.; Henclik, A.; Gorazda, K.; Wzorek, Z. The possible use of sewage sludge ash (SSA) in the construction industry as a way towards a circular economy. J. Clean. Prod. 2015, 95, 45-54. [CrossRef]

27. Supino, S.; Malandrino, O.; Testa, M.; Sica, D. Sustainability in the EU cement industry: The Italian and German experiences. J. Clean. Prod. 2016, 112, 430-442. [CrossRef]

28. Khatib, J.M.; Herki, B.A.; Kenai, S. Capillarity of concrete incorporating waste foundry sand. Constr. Build. Mater. 2013, 47, 867-871. [CrossRef]

29. Torkittikul, P.; Chaipanich, A. Utilization of ceramic waste as fine aggregate within Portland cement and fly ash concretes. Cem. Concr. Compos. 2010, 32, 440-449. [CrossRef]

30. Lim, J.S.; Cheah, C.B.; Ramli, M.B. The setting behavior, mechanical properties and drying shrinkage of ternary blended concrete containing granite quarry dust and processed steel slag aggregate. Constr. Build. Mater. 2019, 215, 447-461. [CrossRef]

31. Ukpata, J.; Ephraim, M.; Akeke, G. Compressive strength of concrete using lateritic sand and quarry dust as fine aggregate. ARPN J. Eng. Appl. Sci. 2012, 7, 81-92.

32. Limbachiya, M.C. Recycled aggregates: Production, properties and value-added sustainable applications. J. Wuhan Univ. Technol. Sci. Ed. 2010, 25, 1011-1016. [CrossRef]

33. Xie, J.; Liu, J.; Liu, F.; Wang, J.; Huang, P. Investigation of a new lightweight green concrete containing sludge ceramsite and recycled fine aggregates. J. Clean. Prod. 2019, 235, 1240-1254. [CrossRef]

34. Lu, J.-X.; Yan, X.; He, P.; Poon, C.S. Sustainable design of pervious concrete using waste glass and recycled concrete aggregate. J. Clean. Prod. 2019, 234, 1102-1112. [CrossRef]

35. Tabsh, S.W.; Abdelfatah, A.S. Influence of recycled concrete aggregates on strength properties of concrete. Constr. Build. Mater. 2009, 23, 1163-1167. [CrossRef]

36. Radonjanin, V.; Malešev, M.; Marinković, S.; Al Malty, A.E.S. Green recycled aggregate concrete. Constr. Build. Mater. 2013, 47, 1503-1511. [CrossRef]

37. Kou, S.C.; Poon, C.S. Enhancing the durability properties of concrete prepared with coarse recycled aggregate. Constr. Build. Mater. 2012, 35, 69-76. [CrossRef]

38. Eguchi, K.; Teranishi, K.; Nakagome, A.; Kishimoto, H.; Shinozaki, K.; Narikawa, M. Application of recycled coarse aggregate by mixture to concrete construction. Constr. Build. Mater. 2007, 21, 1542-1551. [CrossRef]

39. Limbachiya, M.; Meddah, M.S.; Ouchagour, Y. Use of recycled concrete aggregate in fly-ash concrete. Constr. Build. Mater. 2011, 27, 439-449. [CrossRef] 
40. Thomas, C.; Setién, J.; Polanco, J.A.; Alaejos, P.; Sánchez de Juan, M. Durability of recycled aggregate concrete. Constr. Build. Mater. 2013, 40, 1054-1065. [CrossRef]

41. Zimbili, O.; Salim, W.; Ndambuki, J. A Review on the Usage of Ceramic Wastes in Concrete Production. Int. J. Civil Archit. Struct. Constr. Eng. 2014, 8, 91-95.

42. Tavakoli, D.; Heidari, A.; Karimian, M. Properties of concretes produced with waste ceramic tile aggregate. Asian J. Civ. Eng. 2013, 14, 369-382.

43. Rodríguez-Robles, D.; García-González, J.; Juan-Valdés, A.; Morán-del Pozo, J.; Guerra-Romero, M. Quality Assessment of Mixed and Ceramic Recycled Aggregates from Construction and Demolition Wastes in the Concrete Manufacture According to the Spanish Standard. Materials 2014, 7, 5843-5857. [CrossRef]

44. Gonzalez-Corominas, A.; Etxeberria, M. Properties of high performance concrete made with recycled fine ceramic and coarse mixed aggregates. Constr. Build. Mater. 2014, 68, 618-626. [CrossRef]

45. Debieb, F.; Courard, L.; Kenai, S.; Degeimbre, R. Mechanical and durability properties of concrete using contaminated recycled aggregates. Cem. Concr. Compos. 2010, 32, 421-426. [CrossRef]

46. López, V.; Llamas, B.; Juan, A.; Morán, J.M.; Guerra, I. Eco-Efficient Concretes: Impact of the Use of White Ceramic Powder on the Mechanical Properties of Concrete. Biosyst. Eng. 2007, 96, 559-564. [CrossRef]

47. Guerra, I.; Vivar, I.; Llamas, B.; Juan, A.; Moran, J. Eco-efficient concretes: The effects of using recycled ceramic material from sanitary installations on the mechanical properties of concrete. Waste Manag. 2009, 29, 643-646. [CrossRef]

48. Pacheco-Torgal, F.; Jalali, S. Compressive strength and durability properties of ceramic wastes based concrete. Mater. Struct. 2011, 44, 155-167. [CrossRef]

49. Pacheco, J.; de Brito, J.; Chastre, C.; Evangelista, L. Experimental investigation on the variability of the main mechanical properties of concrete produced with coarse recycled concrete aggregates. Constr. Build. Mater. 2019, 201, 110-120. [CrossRef]

50. Liu, H.; Zhang, J.; Zhou, N.; Guo, Y.; Li, B.; Yan, H.; Deng, X. Investigation of spatial stratified heterogeneity of cemented paste backfill characteristics in construction demolition waste recycled aggregates. J. Clean. Prod. 2020, 249, 119332. [CrossRef]

51. Cabrera, M.; Galvín, A.P.; Agrela, F. Leaching issues in recycled aggregate concrete. In New Trends in Eco-Efficient and Recycled Concrete; Elsevier: Amsterdam, The Nethrelands, 2019; pp. 329-356.

52. Sani, D.; Moriconi, G.; Fava, G.; Corinaldesi, V. Leaching and mechanical behaviour of concrete manufactured with recycled aggregates. Waste Manag. 2005, 25, 177-182. [CrossRef] [PubMed]

53. Thole, B.; Mtalo, F.; Masamba, W. Groundwater Defluoridation with Raw Bauxite, Gypsum, Magnesite, and Their Composites. CLEAN Soil Air Water 2012, 40, 1222-1228. [CrossRef]

54. Erdem, S.; Blankson, M.A. Environmental performance and mechanical analysis of concrete containing recycled asphalt pavement (RAP) and waste precast concrete as aggregate. J. Hazard. Mater. 2014, 264, 403-410. [CrossRef] [PubMed]

55. Galvín, A.P.; Agrela, F.; Ayuso, J.; Beltrán, M.G.; Barbudo, A. Leaching assessment of concrete made of recycled coarse aggregate: Physical and environmental characterisation of aggregates and hardened concrete. Waste Manag. 2014, 34, 1693-1704. [CrossRef]

56. Miličević, I.; Bjegović, D.; Siddique, R. Experimental research of concrete floor blocks with crushed bricks and tiles aggregate. Constr. Build. Mater. 2015, 94, 775-783. [CrossRef]

57. Senthamarai, R.; Devadas Manoharan, P. Concrete with ceramic waste aggregate. Cem. Concr. Compos. 2005, 27, 910-913. [CrossRef]

58. Collivignarelli, M.C.; Abbà, A.; Sorlini, S.; Bruggi, M. Evaluation of concrete production with solid residues obtained from fluidized-bed incineration of MSW-derived solid recovered fuel (SRF). J. Mater. Cycles Waste Manag. 2017, 19, 1374-1383. [CrossRef]

59. López-Uceda, A.; Galvín, A.P.; Barbudo, A.; Ayuso, J. Long-Term leaching and mechanical behaviour at recycled aggregate with different gypsum contents. Environ. Sci. Pollut. Res. 2019, 26, 35565-35573. [CrossRef] [PubMed]

60. Medina, C.; Frías, M.; Sánchez de Rojas, M.I. Leaching in concretes containing recycled ceramic aggregate from the sanitary ware industry. J. Clean. Prod. 2014, 66, 85-91. [CrossRef]

61. Wu, K.; Shi, H.; Guo, X. Utilization of municipal solid waste incineration fly ash for sulfoaluminate cement clinker production. Waste Manag. 2011, 31, 2001-2008. [CrossRef] 
62. Wu, K.; Shi, H.; De Schutter, G.; Guo, X.; Ye, G. Preparation of alinite cement from municipal solid waste incineration fly ash. Cem. Concr. Compos. 2012, 34, 322-327. [CrossRef]

63. Saikia, N.; Mertens, G.; Van Balen, K.; Elsen, J.; Van Gerven, T.; Vandecasteele, C. Pre-Treatment of municipal solid waste incineration (MSWI) bottom ash for utilisation in cement mortar. Constr. Build. Mater. 2015, 96, 76-85. [CrossRef]

64. Cheng, A. Effect of incinerator bottom ash properties on mechanical and pore size of blended cement mortars. Mater. Des. 2012, 36, 859-864. [CrossRef]

65. Sorlini, S.; Abbà, A.; Collivignarelli, C. Recovery of MSWI and soil washing residues as concrete aggregates. Waste Manag. 2011, 31, 289-297. [CrossRef]

66. Lynn, C.J.; Dhir, R.K.; Ghataora, G.S.; West, R.P. Sewage sludge ash characteristics and potential for use in concrete. Constr. Build. Mater. 2015, 98, 767-779. [CrossRef]

67. Świerczek, L.; Cieślik, B.M.; Konieczka, P. The potential of raw sewage sludge in construction industry-A review. J. Clean. Prod. 2018, 200, 342-356. [CrossRef]

68. Cioffi, R.; Colangelo, F.; Montagnaro, F.; Santoro, L. Manufacture of artificial aggregate using MSWI bottom ash. Waste Manag. 2011, 31, 281-288. [CrossRef]

69. Van der Wegen, G.; Hofstra, U.; Speerstra, J. Upgraded MSWI Bottom Ash as Aggregate in Concrete. Waste Biomass Valoriz. 2013, 4, 737-743. [CrossRef]

70. Abbà, A.; Collivignarelli, M.C.; Sorlini, S.; Bruggi, M. On the reliability of reusing bottom ash from municipal solid waste incineration as aggregate in concrete. Compos. Part B Eng. 2014, 58, 502-509. [CrossRef]

71. De Lima, F.; Ingunza, D.; del Pilar, M. Effects of Sewage Sludge Ashes Addition in Portland Cement Concretes. In Proceedings of the 2nd International Conference on Civil, Materials and Environmental Sciences, London, UK, 13-14 March 2015; Atlantis Press: Paris, France, 2015.

72. Jamshidi, M.; Jamshidi, A.; Mehrdadi, N.; Pacheco-Torgal, F. Mechanical performance and capillary water absorption of sewage sludge ash concrete (SSAC). Int. J. Sustain. Eng. 2012, 5, 228-234. [CrossRef]

73. Lynn, C.J.; Dhir, R.K.; Ghataora, G.S. Municipal incinerated bottom ash characteristics and potential for use as aggregate in concrete. Constr. Build. Mater. 2016, 127, 504-517. [CrossRef]

74. Sorlini, S.; Collivignarelli, M.C.; Abbà, A. From waste to concrete: An experience of resuse of mswi slags as recycled aggregate in concrete kerbs and flat tiles. In Proceedings of the 3rd International Conference on Industrial and Hazardous Waste Management, Chania, Greece, 12-14 September 2012; p. 8.

75. Tang, P.; Yu, Q.L.; Yu, R.; Brouwers, H.J.H. The application of MSWI bottom ash fines in high performance concrete. In Proceedings of the 1st International Conference on the Chemistry of Construction Materials, Berlin, Germany, 7-9 October 2013.

76. Keulen, A.; van Zomeren, A.; Harpe, P.; Aarnink, W.; Simons, H.A.E.; Brouwers, H.J.H. High performance of treated and washed MSWI bottom ash granulates as natural aggregate replacement within earth-moist concrete. Waste Manag. 2016, 49, 83-95. [CrossRef]

77. Sorlini, S.; Collivignarelli, M.C.; Abbà, A. Leaching behaviour of municipal solid waste incineration bottom ash: From granular material to monolithic concrete. Waste Manag. Res. 2017, 35, 978-990. [CrossRef]

78. Ginés, O.; Chimenos, J.M.; Vizcarro, A.; Formosa, J.; Rosell, J.R. Combined use of MSWI bottom ash and fly ash as aggregate in concrete formulation: Environmental and mechanical considerations. J. Hazard. Mater. 2009, 169, 643-650. [CrossRef]

79. Saikia, N.; Cornelis, G.; Mertens, G.; Elsen, J.; Van Balen, K.; Van Gerven, T.; Vandecasteele, C. Assessment of $\mathrm{Pb}$-slag, MSWI bottom ash and boiler and fly ash for using as a fine aggregate in cement mortar. J. Hazard. Mater. 2008, 154, 766-777. [CrossRef]

80. Siddique, R.; Singh, G. Utilization of waste foundry sand (WFS) in concrete manufacturing. Resour. Conserv. Recycl. 2011, 55, 885-892. [CrossRef]

81. Basar, H.M.; Deveci Aksoy, N. The effect of waste foundry sand (WFS) as partial replacement of sand on the mechanical, leaching and micro-structural characteristics of ready-mixed concrete. Constr. Build. Mater. 2012, 35, 508-515. [CrossRef]

82. Rashad, A.M.; Sadek, D.M.; Hassan, H.A. An investigation on blast-furnace stag as fine aggregate in alkali-activated slag mortars subjected to elevated temperatures. J. Clean. Prod. 2016, 112, 1086-1096. [CrossRef]

83. Yüksel, İ.; Bilir, T.; Özkan, Ö. Durability of concrete incorporating non-ground blast furnace slag and bottom ash as fine aggregate. Build. Environ. 2007, 42, 2651-2659. [CrossRef] 
84. Pan, D.; Li, L.; Tian, X.; Wu, Y.; Cheng, N.; Yu, H. A review on lead slag generation, characteristics, and utilization. Resour. Conserv. Recycl. 2019, 146, 140-155. [CrossRef]

85. Buzatu, T.; Talpoş, E.; Petrescu, M.I.; Ghica, V.G.; Iacob, G.; Buzatu, M. Utilization of granulated lead slag as a structural material in roads constructions. J. Mater. Cycles Waste Manag. 2015, 17, 707-717. [CrossRef]

86. Alwaeli, M. Application of granulated lead-zinc slag in concrete as an opportunity to save natural resources. Radiat. Phys. Chem. 2013, 83, 54-60. [CrossRef]

87. Coppola, L.; Buoso, A.; Coffetti, D.; Kara, P.; Lorenzi, S. Electric arc furnace granulated slag for sustainable concrete. Constr. Build. Mater. 2016, 123, 115-119. [CrossRef]

88. Etxeberria, M.; Pacheco, C.; Meneses, J.M.; Berridi, I. Properties of concrete using metallurgical industrial by-products as aggregates. Constr. Build. Mater. 2010, 24, 1594-1600. [CrossRef]

89. Arribas, I.; Santamaría, A.; Ruiz, E.; Ortega-López, V.; Manso, J.M. Electric arc furnace slag and its use in hydraulic concrete. Constr. Build. Mater. 2015, 90, 68-79. [CrossRef]

90. Rondi, L.; Bregoli, G.; Sorlini, S.; Cominoli, L.; Collivignarelli, C.; Plizzari, G. Concrete with EAF steel slag as aggregate: A comprehensive technical and environmental characterisation. Compos. Part B Eng. 2016, 90, 195-202. [CrossRef]

91. Ozbakkaloglu, T.; Gu, L.; Fallah Pour, A. Normal- and high-strength concretes incorporating air-cooled blast furnace slag coarse aggregates: Effect of slag size and content on the behavior. Constr. Build. Mater. 2016, 126, 138-146. [CrossRef]

92. Valcuende, M.; Benito, F.; Parra, C.; Miñano, I. Shrinkage of self-compacting concrete made with blast furnace slag as fine aggregate. Constr. Build. Mater. 2015, 76, 1-9. [CrossRef]

93. Mosavinezhad, S.H.G.; Nabavi, S.E. Effect of 30\% Ground Granulated Blast Furnace, Lead and Zinc Slags as sand replacements on the strength of concrete. KSCE J. Civ. Eng. 2012, 16, 989-993. [CrossRef]

94. Dinakar, P.; Sethy, K.P.; Sahoo, U.C. Design of self-compacting concrete with ground granulated blast furnace slag. Mater. Des. 2013, 43, 161-169. [CrossRef]

95. Siddique, R.; de Schutter, G.; Noumowe, A. Effect of used-foundry sand on the mechanical properties of concrete. Constr. Build. Mater. 2009, 23, 976-980. [CrossRef]

96. Teng, S.; Lim, T.Y.D.; Sabet Divsholi, B. Durability and mechanical properties of high strength concrete incorporating ultra fine Ground Granulated Blast-furnace Slag. Constr. Build. Mater. 2013, 40, 875-881. [CrossRef]

97. Siddique, R.; Kaur, D. Properties of concrete containing ground granulated blast furnace slag (GGBFS) at elevated temperatures. J. Adv. Res. 2012, 3, 45-51. [CrossRef]

98. Monosi, S.; Ruello, M.L.; Sani, D. Electric arc furnace slag as natural aggregate replacement in concrete production. Cem. Concr. Compos. 2016, 66, 66-72. [CrossRef]

99. Panda, C.R.; Mishra, K.K.; Panda, K.C.; Nayak, B.D.; Nayak, B.B. Environmental and technical assessment of ferrochrome slag as concrete aggregate material. Constr. Build. Mater. 2013, 49, 262-271. [CrossRef]

100. Singh, G.; Siddique, R. Effect of waste foundry sand (WFS) as partial replacement of sand on the strength, ultrasonic pulse velocity and permeability of concrete. Constr. Build. Mater. 2012, 26, 416-422. [CrossRef]

101. Siddique, R.; Singh, G.; Belarbi, R.; Ait-Mokhtar, K. Kunal Comparative investigation on the influence of spent foundry sand as partial replacement of fine aggregates on the properties of two grades of concrete. Constr. Build. Mater. 2015, 83, 216-222. [CrossRef]

102. Manso, J.M.; Polanco, J.A.; Losañez, M.; González, J.J. Durability of concrete made with EAF slag as aggregate. Cem. Concr. Compos. 2006, 28, 528-534. [CrossRef]

103. Gesoğlu, M.; Güneyisi, E.; Mahmood, S.F.; Öz, H.Ö.; Mermerdaş, K. Recycling ground granulated blast furnace slag as cold bonded artificial aggregate partially used in self-compacting concrete. J. Hazard. Mater. 2012, 235-236, 352-358. [CrossRef] [PubMed]

104. Mageswari, M.; Vidivelli, D.B. The Use of Sheet Glass Powder as Fine Aggregate Replacement in Concrete. Open Civ. Eng. J. 2010, 4, 65-71. [CrossRef]

105. Jani, Y.; Hogland, W. Waste glass in the production of cement and concrete-A review. J. Environ. Chem. Eng. 2014, 2, 1767-1775. [CrossRef]

106. Idir, R.; Cyr, M.; Tagnit-Hamou, A. Use of fine glass as ASR inhibitor in glass aggregate mortars. Constr. Build. Mater. 2010, 24, 1309-1312. [CrossRef]

107. Idir, R.; Cyr, M.; Tagnit-Hamou, A. Pozzolanic properties of fine and coarse color-mixed glass cullet. Cem. Concr. Compos. 2011, 33, 19-29. [CrossRef] 
108. Degirmenci, N.; Yilmaz, A.; Cakir, O.A. Utilization of waste glass as sand replacement in cement mortar. Indian J. Eng. Mater. Sci. 2011, 18, 303-308.

109. Tan, K.H.; Du, H. Use of waste glass as sand in mortar: Part I-Fresh, mechanical and durability properties. Cem. Concr. Compos. 2013, 35, 109-117. [CrossRef]

110. Ganiron, T.J. Use of Recycled Glass Bottles as Fine Aggregates in Concrete Mixture. Int. J. Adv. Sci. Technol. 2013, 61, 17-28. [CrossRef]

111. Ganiron, T.U., Jr. The Effect of Waste Glass Bottles as an Alternative Coarse Aggregate in Concrete Mixture. Int. J. ICT Aided Archit. Civ. Eng. 2014, 1, 1-10. [CrossRef]

112. Issa, C.A.; Salem, G. Utilization of recycled crumb rubber as fine aggregates in concrete mix design. Constr. Build. Mater. 2013, 42, 48-52. [CrossRef]

113. Ganiron, T.U.J. Pelletized Cut Rubber: An Alternative Coarse Aggregate for Concrete Mixture. Int. J. Adv. Sci. Technol. 2014, 64, 21-30. [CrossRef]

114. Thomas, B.S.; Gupta, R.C.; Kalla, P.; Cseteneyi, L. Strength, abrasion and permeation characteristics of cement concrete containing discarded rubber fine aggregates. Constr. Build. Mater. 2014, 59, 204-212. [CrossRef]

115. Islam, M.J.; Meherier, M.S.; Islam, A.K.M.R. Effects of waste PET as coarse aggregate on the fresh and harden properties of concrete. Constr. Build. Mater. 2016, 125, 946-951. [CrossRef]

116. Topçu, İ.B.; Canbaz, M. Properties of concrete containing waste glass. Cem. Concr. Res. 2004, 34, $267-274$. [CrossRef]

117. Park, S.B.; Lee, B.C.; Kim, J.H. Studies on mechanical properties of concrete containing waste glass aggregate. Cem. Concr. Res. 2004, 34, 2181-2189. [CrossRef]

118. Ismail, Z.Z.; AL-Hashmi, E.A. Recycling of waste glass as a partial replacement for fine aggregate in concrete. Waste Manag. 2009, 29, 655-659. [CrossRef]

119. Sekar, T.; Ganesan, N. Studies on strength characteristics on utilization of waste materials as coarse aggregate in concrete. Int. J. Eng. Sci. Technol. 2011, 3, 5436-5440.

120. Kısacık, İ.E. Using Glass in Concrete. Bachelor's Thesis, Osmangazi University, Eskişehir, Turkey, 2002.

121. Tuncan, M.; Karasu, B.; Yalcin, M. The Suitability for Using Glass And Fly Ash in Portland Cement Concrete. In Proceedings of the Eleventh International Offshore and Polar Engineering Conference, Stavanger, Norway, 17-22 June 2001; Volume 7.

122. Romero, D.; James, J.; Mora, R.; Hays, C.D. Study on the mechanical and environmental properties of concrete containing cathode ray tube glass aggregate. Waste Manag. 2013, 33, 1659-1666. [CrossRef] [PubMed]

123. Al-Sibahy, A.; Edwards, R. Mechanical and thermal properties of novel lightweight concrete mixtures containing recycled glass and metakaolin. Constr. Build. Mater. 2012, 31, 157-167. [CrossRef]

124. Eme, D.B.; Ekwulo, E.O. Effect Of Crushed Glass As Coarse Aggregate For Concrete Pavement. Am. J. Eng. Res. 2018, 7, 336-345.

125. Srivastava, V.; Gautam, S.P.; Agarwal, V.C.; Mehta, P.K. Glass Wastes as Coarse Aggregate in Concrete. J. Environ. Nanotechnol. 2014, 3, 67-71. [CrossRef]

126. Pepe, M.; Toledo Filho, R.D.; Koenders, E.A.B.; Martinelli, E. Alternative processing procedures for recycled aggregates in structural concrete. Constr. Build. Mater. 2014, 69, 124-132. [CrossRef]

127. Hafez, H.; Kurda, R.; Kurda, R.; Al-Hadad, B.; Mustafa, R.; Ali, B. A Critical Review on the Influence of Fine Recycled Aggregates on Technical Performance, Environmental Impact and Cost of Concrete. Appl. Sci. 2020, 10, 1018. [CrossRef]

128. Silva, R.V.; de Brito, J.; Dhir, R.K. Establishing a relationship between modulus of elasticity and compressive strength of recycled aggregate concrete. J. Clean. Prod. 2016, 112, 2171-2186. [CrossRef]

129. Evangelista, L.; Brito, J. Environmental life cycle assessment of concrete made with fine recycled concrete aggregates. In Portugal Sb07-Sustainable Construction, Materials and Practices: Challenge of the Industry for the New Millennium; IOS Press: Amsterdam, The Netherlands, 2007.

130. Estanqueiro, B.; Dinis Silvestre, J.; de Brito, J.; Duarte Pinheiro, M. Environmental life cycle assessment of coarse natural and recycled aggregates for concrete. Eur. J. Environ. Civ. Eng. 2018, 22, 429-449. [CrossRef] 
131. Turk, J.; Cotič, Z.; Mladenovič, A.; Šajna, A. Environmental evaluation of green concretes versus conventional concrete by means of LCA. Waste Manag. 2015, 45, 194-205. [CrossRef]

132. Kurda, R.; Silvestre, J.D.; de Brito, J. Toxicity and environmental and economic performance of fly ash and recycled concrete aggregates use in concrete: A review. Heliyon 2018, 4, e00611. [CrossRef]

(C) 2020 by the authors. Licensee MDPI, Basel, Switzerland. This article is an open access article distributed under the terms and conditions of the Creative Commons Attribution (CC BY) license (http://creativecommons.org/licenses/by/4.0/). 